\title{
El Mosaico (1858-1872): nacionalismo, elites y cultura en la segunda mitad del siglo XIX
}

\author{
Andrés Gordillo Restrepo \\ Université Paris Sorbonne (Francia) \\ a_gordillo2@hotmail.com
}

\begin{abstract}
Resumen
En este artículo se analiza el trabajo llevado a cabo por las elites culturales, encaminado a demostrar a través de la producción literaria, histórica y editorial en general, la existencia de la nación colombiana en el siglo XIX. Se estudia la coyuntura en que se forma la tertulia de $E l$ Mosaico y las diferentes formas asociativas de la "elite cultural" a lo largo de la segunda mitad del siglo, en relación con las luchas de partido y las divisiones ocasionadas por las guerras civiles. La red de distribución de la revista y los patrones de lectura en la época son tema de análisis así como las diversas nociones de "pueblo", "nación", "regeneración" y "federalismo" en las que se encuentran pautas de identidad y donde se vislumbra el complejo y contradictorio proceso de construcción nacional.
\end{abstract}

Palabras clave: NACIONALISMO, ELITES, CULTURA, PRENSA SIGLO XIX, COLOMBIA.

\begin{abstract}
This article will analyze the work carried out by the cultural elite in order to illustrate through literary, historical and editorial production in general, the existence of the Colombian nation in the nineteenth century. It will discuss the circumstances that contributed to the formation of the group known as El Mosaico, as well as other organizations of the 'cultural elite' throughout the second half of the nineteenth century in relation to the struggles of the group and its occasional periods of disunion caused by civil war. The distribution network for the journal as well as its readership during the period will be the theme of analysis for such diverse notions as 'people' (pueblo), 'nation' (nación), 'reform' (regeneración), and 'federalism' (federalismo), which set the guides for the identity and location of the complex and contradictory process of national construction.
\end{abstract}

Key words: NATIONALISM, ELITES, CULTURE, 19TH CENTURY PRESS, COLOMBIA. 


\section{Introducción $^{1}$}

El presente artículo tiene como fuente principal tres de los primeros años de la revista $E l$ Mosaico. El análisis de esta publicación, una de las más consultadas por el público que visita la hemeroteca de la Biblioteca Nacional, constituye un aporte a la historia de la prensa y la historia intelectual en Colombia, en la medida en que ilumina una época poco conocida de la intelectualidad colombiana, los años 1858-1872, tan poco estudiados y sin embargo tan apasionantes como todo el resto del siglo XIX.

Son años de cambio, como lo refleja la revista, de adaptación a nuevos lenguajes y formas de legitimidad, en los que la elite intelectual escribe mucho, opina, se asocia para promover proyectos culturales, busca salidas a las crisis constantes de la política y crea escenarios de mutua inteligibilidad en el campo de la cultura y en torno a consensos básicos; espacios que sin embargo, el ardor de la política o las "contradicciones de partido" acaban por disolver. A la luz de esta publicación las acciones de estos grupos de personas aparecen múltiples, en ninguna manera constreñidos por las contemporáneas divisiones del trabajo científico, de modo que en el análisis de El Mosaico se aprecian unos intelectuales multifacéticos, ya preocupados por la literatura y la historia, la gramática o la filología, la poesía, el estudio de las costumbres y la política, la geografía y la industria editorial. A lo largo del texto, sugerimos que una pauta de orden de estas múltiples actividades es la preocupación nacionalista, que enmarca y da coherencia a las diversas actividades de estos intelectuales; preocupación que aunque parezca paradójico, se debe en parte a su cosmopolitismo.

Sin embargo, se debe reconocer necesariamente lo mucho que aún se puede hacer para enriquecer los análisis sobre las elites culturales en esta época, empezando por la urgencia de definir o delimitar conceptualmente lo que "elite intelectual" puede querer decir en el contexto colombiano, donde si la política no toca al intelectual es por alguna causa extraña.

El tema de la formación de la nación, del nacionalismo mejor, que estudiamos aquí, es sumamente vasto y son muchos los aspectos que deja abiertos o apenas insinuados para futuras investigaciones. Por ejemplo, aunque lo que en este artículo se propone es reconocer la importancia de las elites intelectuales en el proceso de formación del nacionalismo, cabe sin duda relativizar el papel que ellas desempeñaron en el mismo. Por un lado, no sabemos aún qué conciencia nacional podría tener un iletrado en la segunda mitad del siglo XIX y de qué manera se podía expresar el sentimiento nacionalista en sectores "subalternos". Por otra parte, si estas elites, cumplieron un rol importantísimo en el plano de la creencia, de la construcción de una

\footnotetext{
${ }^{1}$ Este artículo es la versión corregida de un trabajo presentado en la Universidad de la Sorbona en octubre de 2001, para obtener un DEA de "Historia contemporánea de mundos extranjeros y relaciones internacionales" dirigido por François-Xavier Guerra. A él debo agradecer muy especialmente por sus buenos consejos y disponibilidad. Si no fuera por su empuje, este trabajo quizás no existiría. Por eso se lo dedico de manera póstuma como homenaje a su memoria. También quiero mencionar a otras personas, que me han sido de gran ayuda. Zandra Pedraza y Mario González Restrepo, me han dado mucho apoyo y estímulo. Olga Restrepo, en York, tuvo la amabilidad de leer y corregir una primera versión de este trabajo; sus consejos fueron preciosos. Por supuesto los errores que se encuentran en este artículo son mi responsabilidad.
} 
identidad, sirviéndose de mecanismos que le son a primera vista propios en el siglo XIX, como la imprenta, no es menos cierto que la nación depende sobre todo de un tejido de relaciones y filiaciones que en la base son de tipo político. De ello no hacemos mención en este trabajo, en donde nos referimos a la historia política sólo para enmarcar las acciones y posiciones que fueron adoptando las elites culturales que tomaron en un momento dado la iniciativa de formar y fortalecer una cultura nacional.

Puntualmente, en este artículo, donde iniciamos con un repaso por el mundo de las asociaciones culturales en Bogotá para la época en que se funda la revista, se dedica un aparte a los datos relevantes acerca del público lector y la red de colaboradores que tejió el Mosaico con un criterio patriótico y elitista; la falta de otras cifras complementarias relativas a la lectura, a la circulación de la prensa y a los usos de la imprenta en el siglo XIX, es uno de los obstáculos que impiden llegar a un grado de análisis mayor de esta información, que sin embargo por si sola arroja algunas interesantes hipótesis. Se analizan también, en el contexto histórico, las preocupaciones principales de los directores de la revista: cómo se volcaron hacia cierto tipo de trabajos históricos que requirieron el desarrollo de competencias específicas y eruditas.

Por supuesto, aparte de examinar la producción de El Mosaico en su conjunto, una parte se consagra a los cuadros de costumbres, que constituyen una puerta por la cual es posible entrar en las representaciones de pueblo y de nación de la época y en el imaginario de los mismos escritores. Para concluir, se presentará un análisis sobre la idea de "regeneración" que presenta José María Vergara, cofundador de El Mosaico, en un capítulo de su historia literaria.

La cuestión del nacionalismo, que como ya lo señalamos articula esta lectura, tiene sus antecedentes, que merecen una somera discusión en esta parte introductoria. A partir del libro clásico de Eric Hobsbawm The invention of tradition (1983), el problema del ascenso de la nación y del nacionalismo, ha empezado a ser cuestionado abiertamente. Para ello ha hecho falta adoptar una actitud crítica que el mismo Hobsbawm, en su libro Nations and nationalism since 1780 (1992), significativamente subtitulado programa, mito, realidad, califica de agnosticismo. Desde la historia, Hobsbawm elabora una oportuna crítica intelectual a los movimientos nacionalistas que aún tienden a renacer en la Europa finisecular, poniendo de presente el carácter artificial de la nación. En efecto, en su obra se desvela el carácter eminentemente moderno de la nación y el voluntarismo subyacente a su emergencia, en contra de las teorías (que son empleadas por los partidos independentistas o de extrema derecha) que la conciben de manera simplista como una comunidad ligada por un vínculo primario. Así, este autor destaca por ejemplo la novedad del concepto: la palabra nación, dice, sólo aparece bajo su definición contemporánea en la edición del diccionario de la Real Academia Española de 1925, cuando la "patria" se define como "nuestra nación, con la suma de todo lo material e inmaterial, el pasado, el presente y el futuro, el cual goza de la lealtad y del amor de los patriotas" 2 .

\footnotetext{
2 Eric Hobsbawm, Nations and Nationalism since 1780. Programm, Myth, Reality (Cambridge: Cambridge University Press, 1992).
} 
Desde el punto de vista de la historia del vocabulario, cabe observar que la palabra nación es más antigua, y que aparece asociada en distintas épocas a diferentes contenidos, a diferentes realidades políticas históricas. Así vemos cómo en el siglo XIX se confunde con Estado, ya que en el periodo revolucionario la nación aparece como el fundamento de éste, que no es otra cosa que el resultado de la propia soberanía de la nación. Pero también, en el siglo XIX, la misma palabra se emplea con un significado más antiguo, que no está asociado a una matriz política sino que remite a una concepción "primordialista" que será explotada por los movimientos nacionalistas, para evocar raza y pueblo, pero no el pueblo de la filosofía política, del contrato social, sino un "linaje" que comparte un mismo origen, lengua y tradiciones.

En la línea de Hobsbawm, otros autores se han ocupado en la identificación de los mecanismos por los cuales se da el ascenso de una conciencia nacional en los diferentes países. En este proceso, del que se han distinguido diferentes etapas, varios autores parecen acordar a las elites culturales y a los hacedores de memoria un papel destacado. Así por ejemplo, en un trabajo reciente referido al caso europeo, Anne Marie Thiesse ${ }^{3}$ descubre los esfuerzos, llevados a cabo por las elites culturales europeas, con el fin de crear o identificar una cantidad de monumentos e hitos simbólicos (literarios, por ejemplo) que hablen de la antigüedad de la nación, de los antepasados comunes, y de una identidad cultural propia. "El verdadero nacimiento de una nación - dice esta autora, enfatizando en el carácter artesanal de la nación- se da cuando un puñado de individuos declara que ella existe y se dedica a probarlo" ${ }^{4}$. Por ello, no es de extrañar que en el camino de esta acción cultural, la creación y defensa de las culturas nacionales y la "nacionalización" de unas elites caracterizadas por su cosmopolitismo, se verifique en paralelo una revolución estética donde la nación, lo particular, sustituye la cultura universal del clasicismo.

En realidad, las manifestaciones del nacionalismo en las artes y en el ámbito cultural son múltiples en el siglo XIX. Se encuentran en la literatura, la música y la pintura, y también en la historia, los relatos de viajes y la antropología, por ejemplo. Pero quizás, como ya lo han anotado algunos autores, es en la filología en donde se hace más evidente el voluntarismo de unas elites culturales que llevaron las lenguas vernáculas de la aldea al nuevo estatus de lengua oficial. Ello ha servido para que Benedict Anderson en Comunidades imaginadas, caracterizara éste como un siglo dorado para filólogos y gramáticos, quienes recogieron la ecuación herderiana por la cual una nación es igual a una lengua.

Con razón, debe admitirse de antemano que el problema de la emergencia en Hispanoamérica del modelo nacional, fundado en relación con un paradigma europeo de homogeneidad, unidad e indivisibilidad, debe considerarse en un marco histórico preciso, sin desconocer las particularidades del proceso de emancipación política, las continuidades y discontinuidades con el mundo europeo en el plano cultural, ni las especificidades mismas del desarrollo y funcionamiento político y cultural de estas sociedades.

\footnotetext{
${ }^{3}$ Anne Marie Thiesse, La création des identités nationales. Europe XVIIIe-XXe siècle (París: Seuil, 1999).

${ }^{4}$ Ibídem, 11. Traducción del autor.
} 
De hecho, en el plano de la interpretación histórica se han producido discusiones importantes que invitan a renovar el debate sobre la cuestión nacional. Hasta no hace mucho, el proceso revolucionario de la Independencia, que puede sintetizarse "en el planteamiento radical que condujo al establecimiento de la soberanía en la nación" " , se presentaba por los historiadores tradicionales, (empezando por José Manuel Restrepo) como la lucha por la emancipación de naciones preexistentes. Entre tanto se olvidaban las características globales del proceso de emergencia de la nación y las circunstancias abruptas de su irrupción en América Latina. Así, por ejemplo, la invasión napoleónica, en el origen de la crisis de la monarquía española, ya ha empezado a dejar de aparecer en segunda línea entre las causas de la Independencia. Y se acepta, luego de una interpretación menos lisonjera como la que hace François-Xavier Guerra sobre el advenimiento de la modernidad política en Hispanoamérica ${ }^{6}$, que los principales desafíos que se presentaron a las nuevas elites frente al desmoronamiento de la monarquía española fueron (ciertamente en orden contrario al que se suele pensar) el de la construcción del Estado y, en seguida, el de la construcción nacional.

Para el caso colombiano, se han efectuado ya un buen número de trabajos que conservan una posición crítica frente al discurso histórico "patriótico", esa "prisión historiográfica" como la llamó Germán Colmenares. En esta línea cabe destacar los trabajos más recientes que, con base en nuevos datos, buscan establecer por ejemplo si es posible (y en qué términos), hablar de la existencia de una elite protonacional durante la época colonial. En estos enfoques ha primado la prevención de dejar a un lado las visiones teleológicas que buscan en la Colonia las causas de la Independencia ${ }^{7}$. En contraste, son pocos los trabajos que abordan el tema del nacionalismo en el periodo consecutivo a la proclamación de la Independencia, que es el que correspondería a la consolidación misma de la nación.

\footnotetext{
${ }^{5}$ François-Xavier Guerra, Modernidad e independencia. Ensayos sobre las revoluciones hispánicas (Madrid: Editorial MAPFRE, 1992).

${ }^{6}$ Ibídem.

${ }^{7}$ Ver Jorge Orlando Melo, "La literatura histórica en la república", en Manual de Literatura colombiana, 2 vols (Bogotá: Procultura; Planeta 1988); Germán Colmenares, Partidos políticos y clases sociales (Bogotá: Universidad de los Andes, 1968); Marco Palacios, "La fragmentación regional de las clases dominantes en Colombia. Una perspectiva histórica", en Estado y clases sociales en Colombia (Bogotá: Procultura, 1986); Margarita Garrido, "La Política local en la Nueva Granada, 1750-1810", Anuario Colombiano de Historia Social y de la Cultura, no. 15 (1987); Reclamos y Representaciones. Variaciones sobre la politica en el Nuevo Reino de Granada, 1770-1815 (Bogotá: Banco de la República, 1993); "Propuestas de identidad política para los colombianos en el primer siglo de la República", en Javier Guerrero, comp., Memorias del IX Congreso de Historia. Iglesia, movimientos y partidos: Política y violencia en la historia de Colombia, vol 3 (Tunja: Universidad Pedagógica y Tecnológica de Colombia, 1995); Jaime Jaramillo Uribe, "Nación y región en los orígenes del Estado Nacional en Colombia", en Ensayos de historia social, tomo 2 (Bogotá: Tercer Mundo Editores; Ediciones Uniandes, 1989); Alfonso Múnera, El fracaso de la nación. Región, clase y raza en el Caribe colombiano (1717-1810) (Bogotá: Banco de la República; El Ancora editores, 1998); Fernán González, "Ciudadanía e identidad nacional. Los desafíos de la globalización y diferenciación cultural al Estado Nación”, ponencia presentada al XI Congreso Colombiano de Historia, (Bogotá: Agosto 22 al 25 de 2000).
} 
Cabe mencionar sin embargo dos trabajos europeos: la tesis de habilitación del alemán HansJoachim König, titulada En el camino hacia la nación $(1994)^{8}$, y la tesis doctoral del francés Frédéric Martínez, El nacionalismo cosmopolita (2001), recientemente publicada ${ }^{9}$.

La cronología de ambos estudios abarca todo el siglo XIX. El trabajo de König, por su lado, aborda las primeras manifestaciones de patriotismo en la Nueva Granada, desde las últimas décadas de la colonia hasta mediados del siglo XIX. En este periodo se pueden diferenciar cuatro etapas: la primera corresponde al patriotismo naciente de las sociedades de amigos del país en el periodo colonial ${ }^{10}$; la segunda a la época de las guerras de independencia, a un discurso continental de anticolonialismo, donde se vuelve recurrente el tema de la lucha contra la "tiranía" y la oposición entre Europa y América; la tercera, se asimila a la definición de los límites de la Nueva Granada con el fin de la Gran Colombia, a la consolidación del territorio y a un nacionalismo republicano; la cuarta, por fin, remite al discurso nacional del movimiento artesano liderado por Melo en 1854, que representa un breve paréntesis dentro del nacionalismo elitista liberal que es dominante en estas décadas. Las manifestaciones nacionalistas que estudia König para el periodo independiente, estarían patentes a lo largo del siglo XIX en la adopción y creación de símbolos nacionales, y de manera permanente en la retórica política.

De otro lado, Frédéric Martínez elabora un análisis de la referencia europea del discurso nacionalista colombiano desde una perspectiva innovadora, indagando por el uso, por parte de las diferentes facciones políticas en gestación a mediados del siglo XIX. El historiador francés estudia la nacionalización paulatina de unas elites que habían basado en buena parte su legitimidad y hegemonía social en el cosmopolitismo y que habían incluso trazado sus diferencias en una mimesis de la política europea. En su trabajo, Martínez subraya la importancia del viaje a Europa, que empezaría a demostrar a la elite nacional la necesidad de desarrollar una identidad propia. A través de su experiencia directa en un mundo al que estaban muy ligados sentimentalmente, los viajeros colombianos pudieron empezar a constatar la realidad de su marginalidad en la "escena de las naciones". En Europa, además de verse rebajadas socialmente, las elites se enfrentaban a prejuicios de inferioridad y barbarie con los que el mundo occidental - del que se reclamaban no sólo herederos espirituales, sino incluso eminente vanguardia por su republicanismo- los menospreciaba.

En la segunda mitad del siglo XIX al fin, es que debe buscarse esta inflexión en el discurso nacionalista, que cobija cambios importantes en la representación que se hace de sí misma la elite cultural colombiana. Estos cambios se hacen más visibles a través de dos procesos que se encuentran aparentemente relacionados en esta época, y que ocurren en segundo plano hasta

\footnotetext{
${ }^{8}$ Hans-Joachim König, En el camino hacia la nación. Nacionalismo en el proceso de formación del Estado y de la nación de la Nueva Granada, 1750-1856 (Bogotá: Banco de la República, 1994).

${ }^{9}$ Frédéric Martínez, El nacionalismo cosmopolita. La referencia europea en la construcción nacional en Colombia, 1845-1900 (Bogotá: Banco de la República; Instituto Francés de Estudios Andinos, 2001).

${ }^{10} \mathrm{El}$ desarrollo de una conciencia protonacional, que ha sido estudiada desde el ordenamiento jurídico colonial por Margarita Garrido (1993), es un tema de debate. Ver: González, "Ciudadanía e identidad”. Para este periodo König señala como el referente en muchos de los discursos de las sociedades de amigos del país es ya el Reino de la Nueva Granada y no el conjunto de la monarquía española.
} 
llegar a su apogeo durante La Regeneración. Por una parte, se produce en el campo literario un cambio en los intereses, se empieza a ver una creciente preocupación por definir y crear una literatura y un arte propiamente nacionales por oposición al universalista y cosmopolita ${ }^{11}$. Por otra parte las elites, sobre todo las conservadoras que estuvieron más comprometidas en este cambio cultural que las liberales, empiezan a relativizar los valores aceptados como "naturalmente buenos" de las instituciones republicanas, pretextando la reconstrucción del "buen gobierno" sobre las bases propias del "pasado nacional" más allá de la forma de las instituciones.

\section{Tertulias y academias en la segunda mitad del siglo XIX}

La tertulia de El Mosaico apareció en Bogotá en el segundo semestre de 1858, con el objeto de llenar un doble vacío. Por una parte el que representaba la ausencia de instituciones orientadas al fomento de las artes y de la literatura en el país. Por otra, el que correspondía a la impresión vivida por la elite cultural de un decaimiento de la vida social, manifiesto en un embotamiento de la vida asociativa del que únicamente se salía de cuando en cuando con las fiestas cívicas y religiosas, así como con algunos eventos sociales excepcionales que rompían la rutina diaria como matrimonios y entierros.

Con respecto al vacío de instituciones culturales, El Mosaico vendrá efectivamente a romper una cadena de fracasos acumulados por parte del Estado. A lo largo del siglo se habían presentado algunas iniciativas estatales orientadas al fomento de la literatura y las artes, pero estos empeños desde arriba por crear instituciones culturales habían fracasado repetidamente. Las comunidades científicas y académicas que se habían concebido con tanto entusiasmo y ambición después de la Independencia no alcanzaron a tener mayor continuidad. De ellas, entre las que se cuentan los proyectos de 1826 y 1832 de crear una Academia Nacional semejante al Instituto Real de Francia, sólo permanecía en pie para 1858 un Museo Nacional empobrecido y saqueado que tenía dificultades para funcionar normalmente ${ }^{12}$. Entre tanto, las dificultades presupuestarias, la gran inestabilidad política, y la falta de una verdadera comunidad académica, hacían que la idea de consolidar una elite literaria, científica y artística en el país, a partir de la iniciativa del Estado, fuera meramente utópica.

Aún en la segunda mitad del siglo, y ya no siempre bajo la tutela de un Estado que se reduce a su mínima expresión con el federalismo, la viabilidad de las asociaciones de carácter cultural sigue siendo mínima. Esto lo confirma por ejemplo el caso del Liceo Granadino, una asociación semipública, financiada por las donaciones de los asistentes o socios, según el modelo del Liceo Artístico y Literario Español, que no logró funcionar en Bogotá sino poco más de un año. Durante el mismo periodo también fracasarían dos iniciativas gubernamentales: el Conservatorio Nacional de Ciencias y Artes (1855) y por tercera vez la deseada Academia

\footnotetext{
${ }^{11}$ Pero debe aclararse: el que dice universalismo en esta época, a mediados del siglo XIX, piensa más en la Francia que exporta su literatura al mundo entero que en la antigüedad clásica.

${ }_{12}$ Marta Segura, Itinerario del Museo Nacional de Colombia 1823-1994 (Bogotá: Instituto Colombiano de Cultura; Museo Nacional de Colombia, 1995).
} 
Nacional (1857). Por entonces, sólo la Comisión Corográfica (1850-1859), contratada por Tomás Cipriano de Mosquera podía llenar el vacío de las instituciones científicas, aunque ella respondía a objetivos precisos, enteramente pragmáticos, como lo era establecer una geografía con informaciones básicas sobre el clima, los productos regionales y la población.

En este contexto, sin embargo, no eran raras las asociaciones creadas desde el ámbito privado con el ánimo de dar impulso y cultivar las letras o las ciencias. Entre las asociaciones creadas con el ánimo específico de promover las artes, pueden citarse para la década de los cincuenta cuatro sociedades y una academia, sobre las que sin embargo no se ha realizado un estudio importante: la Sociedad Filarmónica o Lírica $\left(1846-1857\right.$; 1859) ${ }^{13}$, la Sociedad de Dibujo y Pintura (1847), la Academia de Santo Tomás de Aquino (1857), que fue fomentada por los religiosos dominicos, una Sociedad Protectora del Teatro y una Sociedad de Lectura que tuvieron una existencia efímera.

Pero si no se cuenta con trabajos acerca de este tipo de asociaciones constituidas de una manera formal, menos aún es lo que se sabe de las tertulias, que remiten a una práctica relativamente antigua y genérica de sociabilidad que ya empieza a usarse en sentido restringido para designar la reunión informal y típica, en oposición a los más modernos clubes y casinos venidos del extranjero, que se constituían formalmente y se caracterizaban por un mayor grado de organización ${ }^{14}$. No obstante, de este tipo de asociaciones informales, a las que se podría seguir la pista a partir de las últimas décadas del siglo XVIII, y de las que se destacan las famosas tertulias de Antonio Nariño y de Manuel del Socorro Rodríguez, son muy pocas las que se encuentran en actividad o mejor, de las que se tiene noticia en Bogotá para 1858.

\footnotetext{
${ }^{13}$ Jesús Duarte y María V. Rodríguez, "La sociedad Filarmónica y la cultura musical en Santafé a mediados del siglo XIX", Boletín Cultural y Bibliográfico 28, no. 21 (1991).

${ }^{14}$ Resulta sorprendente y sugestivo para el análisis de las sociabilidades, por ejemplo, ver cómo en las sucesivas ediciones del diccionario de la Real Academia Española se define la palabra "club" desde 1837 de modo negativo, como "junta de individuos de alguna sociedad política clandestina" en contraste con una de las definiciones de tertulia de 1852: “[...] junta de personas de ambos sexos, para conversación, juego y otras diversiones honestas". Un magnífico análisis de las nuevas formas de sociabilidad en Francia en el siglo XIX en Maurice Agulhon, Le cercle dans la France bourgeoise 1810-1848. Etude d'une mutation de sociabilité (Paris: Armand Colin, 1977).
} 


\section{Tabla 1}

\section{Instituciones científicas Colombia Siglo XIX}

\begin{tabular}{|l|l|}
\hline $1783-1816$ & Real Expedición Botánica del Nuevo Reino de Granada \\
\hline $1803 \ldots$ & Observatorio Astronómico Nacional \\
\hline $1823 \ldots$ & Misión Zea-Rivero-Boussignault \\
\hline $1826 ; 1832$ & Museo de Historia Natural y Escuela de Minería (Museo Nacional) \\
\hline & Colegio Militar \\
\hline & Instituto de Ciencias Naturales, Físicas y Matemáticas \\
\hline 1847 & Instituto Caldas \\
\hline & Comisión Corográfica \\
\hline 1855 & Conservatorio Nacional de Ciencias y Artes \\
\hline 1856 & Liceo Granadino \\
\hline 1857 & Academia Nacional \\
\hline & Sociedad de Naturalistas Neogranadinos \\
\hline 1865 & Instituto Nacional de Ciencias y Artes \\
\hline $1867-$ & Universidad Nacional de los Estados Unidos de Colombia \\
\hline $1869-1870$ & Sociedad de Naturalistas Colombianos \\
\hline $1871-$ & Academia Colombiana de la Lengua \\
\hline $1871-1873$ & Academia de Ciencias Naturales \\
\hline $1871-$ & Universidad de Antioquia \\
\hline $1871 \ldots$ & Sociedad de Agricultores Colombianos \\
\hline & Sociedad de Medicina y Ciencias Naturales \\
\hline & Instituto Nacional de Agricultura \\
\hline & Comisión Científica Permanente \\
\hline 1884 & Ateneo Colombiano \\
\hline $1887-$ & Sociedad Colombiana de Ingenieros \\
\hline $1887-$ & Escuela Nacional de Minas \\
\hline $1887-$ & Academia de Medicina de Medellín \\
\hline & Academia Nacional de Medicina \\
\hline & \\
\hline
\end{tabular}

(...) Se ha conservado con intermitencia en su actividad hasta el presente.

(-) Se ha conservado en actividad continua hasta hoy.

Fuente: Olga Restrepo Forero, La Comisión Corográfica, avatares en la configuración del saber (Bogotá: Universidad Nacional, monografías sociológicas, 1988). 


\title{
Una tertulia literaria (bipartidista)
}

\author{
"Mi brindis es muy sencillo: \\ Aunque algunos somos godos, \\ Brindemos alegres todos \\ Por nuestro amigo Murillo" \\ Brindis de Ricardo Carrasquilla en honor \\ al presidente radical Manuel Murillo Toro
}

Entre las asociaciones culturales del siglo XIX, efímeras por definición, sobresale El Mosaico, no sólo por su longevidad (permanecerá catorce años en actividad intermitente), sino también por tratarse de la primera asociación que puede enmarcarse en el conjunto de las modernas agrupaciones literarias. Por otra parte, esta asociación de hombres de letras, llegará a constituir un ejemplo de civilidad y tolerancia en un país aquejado por las animosidades partidistas y las constantes guerras civiles.

Efectivamente, la tertulia, que giraba en torno a la revista homónima, estuvo compuesta por un grupo de publicistas o literatos $^{15}$ de la elite bogotana, identificados tanto con el liberalismo como con el conservatismo nacientes, que se empezaron a reunir de manera informal para discutir de literatura y pasar un "rato agradable" evitando las discusiones políticas. De hecho, fue el masón Rafael Eliseo Santander, representante en el senado, quien empezó a ofrecerse como anfitrión de las reuniones, que al parecer siempre se desarrollaron en un ambiente familiar. En el salón de su casa primero y después, en 1864, en la casa del también liberal José María Samper, o en la de otros de los miembros de la tertulia, se dieron cita de manera periódica doce o más invitados regulares. La mayoría de ellos habían participado en el Liceo Granadino, una asamblea literaria que se reunía mensualmente en el salón de grados con la participación de hombres y mujeres del beau monde ${ }^{16}$. De allí salieron hacia El Mosaico liberales como Salvador Camacho Roldán, Próspero Pereira Gamba y Aníbal Galindo ${ }^{17}$. Y también un grupo de conservadores que, encabezados por José María Vergara y Vergara, asumieron la creación y dirección de la revista. Ellos fueron José Manuel Marroquín, José David Guarín, José Joaquín Borda y Ricardo Carrasquilla, quienes se pusieron en competencia con R. E. Santander que seis meses atrás había creado una revista literaria de circulación nacional, la Biblioteca de

\footnotetext{
${ }^{15}$ En el censo de población de 1870 se encuentra una entrada de "literatos" en la clasificación por actividades económicas. Allí se enumeran 77 literatos hombres y 5 mujeres. Miguel Urrutia y Mario Arrubla, Compendio de estadísticas históricas de Colombia (Bogotá: Universidad Nacional de Colombia, 1970), 29. La denominación de literatos y de publicistas es la más corriente en la revista.

${ }^{16}$ El Liceo Granadino, como ya se mencionó, tuvo como modelo el Liceo Artístico y Literario español. Al igual que esta institución creada en 1837, su par colombiano buscó emprender "la propaganda y el desarrollo de las ciencias, la literatura y las bellas artes", así como contribuir a regularizar el español y a desarrollar el estudio de la historia nacional. Juan Francisco Ortíz, Reminiscencias de D. Juan Francisco Ortíz (opúsculo autobiográfico 1808-1861) con prólogo de D. José Manuel Marroquín (Bogotá: Librería Americana, 1907), 248-258.

${ }^{17}$ Roberto Liévano Reyes, "El mosaico: tertulias literarias en Santafé y Bogotá”, El Gráfico 38, no. 375 (1917).
} 
señoritas $^{18}$. Poco después de su fundación, El Mosaico acabó por absorber a la Biblioteca, asegurándose una hegemonía en el campo de las publicaciones culturales y la colaboración de dos de los más prolíficos escritores de novelas de la época: Soledad Acosta de Samper y Felipe Pérez.

El ambiente entonces era, por cierto, favorable para una asociación bipartidista como lo fue $E l$ Mosaico y poco antes el Liceo Granadino. Después de una época crítica, el segundo lustro de los años 50 parecía prometer una nueva era para el país. La revolución liberal de mediados de siglo, que había provocado una gran volatilidad política y social, venía a decantarse en un pacto de convivencia bipartidista y en la esperanza de acallar los ánimos revolucionarios. En Bogotá, las medidas librecambistas que habían impulsado los radicales a comienzos de los 50, habían alentado los enfrentamientos cada vez más frecuentes y violentos entre los gólgotas y los artesanos que defendían las políticas de protección a las fabricaciones nacionales. La tensionante situación se había complicado aún más con la hostilidad entre los mismos gólgotas y los draconianos, que representaban la vieja guardia de generales de la Independencia en lucha por un espacio político que se reducía por las presiones de los jóvenes radicales. El 17 de abril de 1854, una coalición de draconianos y artesanos acabó por sorprender con un golpe militar que indignó y movilizó a las elites tanto liberales como conservadoras. La respuesta al gobierno golpista, se conformó como una coalición bipartidista, primero militar, que anticipa en muchos aspectos al Frente Nacional. Derrocado Melo en diciembre, reprimido y diezmado el movimiento artesano, el Congreso decidió elegir a un conservador, Manuel María Mallarino, para que liderara como vicepresidente en ausencia del derrocado José María Obando un gobierno de "restauración constitucional". Este gobierno, favorecido por la tolerancia de los liberales radicales y moderados, se apoyó para sus tareas en un gabinete ministerial de conciliación en el que tuvieron representación varios sectores del liberalismo y el conservatismo. Pero sobre todo, durante la presidencia de Mallarino, e incluso durante la posterior del también conservador Mariano Ospina, el fantasma de una revuelta socialista sirvió para garantizar la moderación y como freno a las iniciativas poco consensuales, con lo que se pudo asegurar durante algún tiempo la cohesión de la elite dirigente. Al tiempo, la cautela de esta época se refleja muy bien en otros aspectos, como la preocupación creciente por desterrar a las masas de la política (finalmente se retrotrae el voto universal que los radicales habían instaurado en 1853) y por un discurso conciliador y tolerante que sin embargo estigmatizó al diezmado artesanado como potencial impulsor de la anarquía.

En medio de esta situación es que prospera una iniciativa también bipartidista, pero ahora limitada al ámbito puramente cultural, como lo fue el Liceo Granadino y después El Mosaico, que buscó abstraerse lo más posible de las "luchas de partido" y de la "politiquería". En parte, pues, podría decirse que la tertulia representa para su momento una suerte de frente cultural levantado por la elite social bogotana, que correspondería en otro plano a una respuesta nostálgica de la cultura aristocrática ante el advenimiento de las masas en la república de las

\footnotetext{
${ }^{18}$ Entre los contertulios cabe mencionar también a Manuel Pombo, José María Quijano Otero, Ricardo Becerra, Diego Fallon, Ezequiel Uricoechea, Ricardo Silva, Gregorio Gutiérrez González, Marceliano Vélez y Bernardino Torres Torrente. Jorge Isaacs se incorporaría tardíamente.
} 
letras; advenimiento que ocurriría a través de la incursión de la clase media de artesanos en la cultura letrada a través de la prensa política. Nacida en Bogotá, pero magnificada en una revista de distribución nacional a la que contribuían publicistas y hombres de talento de todo el país, la tertulia ayudaría a facilitar el proceso, torpemente iniciado, de acercamiento de unas elites que, a pesar de encontrarse aisladas geográfica y políticamente entre sí, compartían una misma lengua y una misma educación y valoraban por igual las manifestaciones de una "alta cultura", que peligraba por el positivismo que caracterizaba los tiempos modernos y por la "mediocridad" que impulsaba la democracia.

Sin embargo, estos hermanamientos culturales no siempre transcurrieron sin suspicacias, ni duraron demasiado tiempo. El santo y seña del "amor a lo bello" con el que se daba por sellada la complicidad de las elites de ambos partidos, no era una garantía para evitar las interpelaciones facciosas, más aún cuando era sabido que era un grupo de conservadores el que dirigía la revista. De hecho, los editores tenían que salir de cuando en cuando a desmentir rumores:

Algunos han creído encontrar al Mosaico muy gólgota, y otros muy conservador. Declaramos que El Mosaico no toca nada con la política, y que inserta todo lo que esté bien escrito, sin más excepción que las de aquellos escritos que hieran las opiniones religiosas o la moral, dos santuarios que no profanamos. Por el contrario nos complacemos y nos encaprichamos en reunir los mismos nombres que la política separa y hace enemigos.

El criterio de lo "bien escrito", no parece suficiente en todo caso para obviar las diferencias que irán haciéndose manifiestas con el tiempo en el seno de la misma asociación literaria y que dividirían a término la misma nación. La voluntad de mantener separada la política de la vida intelectual, consagrando un espacio autónomo donde se expresaría el patriotismo desinteresado y no sectario, representaba una tarea improbable; más aún en los momentos críticos cuando la política se volvía demasiado apasionada y los desacuerdos se tornaban manifiestos. En estos momentos críticos, cuando con más claridad se evidencia el valor estratégico de la prensa para ganar adeptos, hasta la prensa literaria se convierte en un nicho desde el cual se puede formar opinión. La profesión literaria, si una prueba hace falta, acá se muestra como era: un imposible; es iluso pensar en esta época en un campo literario o cultural autónomo de las redes del poder.

Una manera simple de comprobar esto sería sintetizando la historia de la revista. Esta conservó durante sus primeros años, e incluso pasada la guerra civil de 1860-63, una misma identidad elitista, hasta julio de 1865 cuando el liberal Felipe Pérez asumió, en cabeza de una "asociación progresista" su dirección: corrían los tiempos de un renovado radicalismo liberal. Entonces, la publicación no llegó a completar en su nuevo carácter -proactivo diríamos hoy- el año, pero los 12 números que aparecieron dejan ver una variante del discurso del liberalismo en el poder. Las muestras de elocuencia sobre el orgullo republicano ganaron espacio, mientras los nuevos directores defendieron la idea de ampliar el público de la revista hasta hacer de ella una lectura "eminentemente popular", que no sólo fuera literaria, sino que también sirviera para inculcar 
conocimientos y dar consejos útiles a los artesanos y los campesinos, integrando una visión de progreso material que estaba ausente en la primera época cuando se fustiga el afán de lucro y se pone el énfasis en la necesidad de trabajar por el "progreso moral" de la sociedad. En esta época se multiplican los relatos de viajes, con las crónicas de la vida europea y norteamericana escritas por Felipe Pérez quien como editorialista no dejó de entrar en polémica política con otros periódicos contemporáneos y con sectores del gobierno.

Después de una pausa de cinco años, se inicia la tercera y última época de El Mosaico (18711872), que transcurre bajo las crecientes tensiones entre liberales y conservadores por la reforma educativa. En esta etapa la revista, que aparece de nuevo dirigida por un Vergara reafirmado en sus convicciones político-religiosas, es manejada ya casi exclusivamente con un espíritu conservador. El Mosaico se asociará con la prensa política y particularmente con El Tradicionista, el periódico de Miguel Antonio Caro que fue creado como órgano del partido católico. La división entonces ya estaba consumada. En su correspondencia con Juan María Gutiérrez, Ezequiel Uricoechea confirma esta ruptura, que debió ser un hecho antes de su partida definitiva de Colombia en 1867.

Estamos de acuerdo, o más bien, lo estoy con U. que es quien ha enunciado la idea, respecto al influjo pernicioso de cierta literatura de la madre patria. Allí [en Colombia] ha habido facilidad en la expresión pero poco fondo y tendencias serviles en muchos. Vergara no le debió a ella el camino que tomó, sino a un círculo político de beatos hambrientos, maldicientes, envidiosos y brutos (así son todos ellos... y Dios se lo perdone que yo no tengo alma para tanto) que hacen carrera a punta de padrenuestros y de meter la uña en los bolsillos del prójimo. Por desgracia se afilió entre ellos y desde entonces tuvimos que vernos menos con él, que antes estaba con nosotros y se acabó "El Mosaico" y casi, casi no volvimos a reunirnos los bibliófilos de los cuales yo era el más antiguo, si no el de mayor edad $^{19}$.

En este mismo período de comienzos de la década de los setenta se crea la Academia de la Lengua, y ya la composición de esta asamblea muestra un cambio notable en las tendencias asociativas de las elites con respecto a los primeros años de la década anterior. Basta decir que apenas dos de los doce primeros miembros de la Academia se identifican con el partido liberal. Uno de ellos, Santiago Pérez, entrará en disputa con Miguel Antonio Caro, hasta el punto de presentarle su indignada renuncia por razones de un diferendo político y es sabido que el fin de la primera época de la Academia coincidirá con la antipatía que se había larvado entre Marroquín y el mismo Caro, ya durante la Regeneración. En cualquier caso, tras el corto periodo de estabilidad en la república de las letras o de calma chicha que imperó en los inicios de El Mosaico, no harán más que acrecentarse las desconfianzas. Por mucho que insistieran sus miembros sobre el carácter apolítico de la Academia, esta institución no dejará de ser el objeto de sospechas constantes por parte de los liberales que verán en todos sus movimientos actos

\footnotetext{
${ }^{19}$ Mario Germán Romero, ed., Epistolario de Ezequiel Uricoechea con Juan María Gutiérrez, varios colombianos y August Friedrich Pott (Bogotá: Instituto Caro y Cuervo).
} 
deliberados aunque simbólicos de restauración monárquica o de conspiración. Así, el congreso de mayorías liberales le negará su apoyo a los académicos cuando éstos solicitaron una sede para sesionar y son conocidas las acusaciones que le lanzaron a los académicos cuando decidieron cambiar la $i$ latina por la $y$ griega en las conjunciones, lo que les valió recibir el título de "soldados póstumos de Felipe II".

A grandes trazos, la trayectoria de la revista, que acaba por disolverse espontáneamente en 1872 tras la muerte de Vergara tiene ese corolario. La misma imprenta de El Mosaico, continuará sin embargo editando literatura nacional durante otros cinco años, ahora bajo el nombre de Imprenta del Tradicionista y bajo los criterios de un Miguel Antonio Caro beligerante ${ }^{20}$. En 1877 la imprenta, que empezó con la esperanza de generar un círculo virtuoso, termina silenciándose en el círculo vicioso de la guerra civil, cuando el gobierno liberal decide su confiscación. Es natural que un proyecto bipartidista, de consensos elementales no pudiera haber cuajado en la década de 1870. Tras la reforma pedagógica y la expedición del Syllabus de Pío Nono en 1864, condenando el liberalismo, el conflicto entre partidos adquirió matices de intolerancia religiosa y de activa intransigencia. La literatura misma pudo haber sido terreno de censuras de parte y parte y de activa propaganda ideológica.

Hasta ahora hemos querido llamar la atención sobre algunos aspectos generales de las tendencias asociativas de las elites culturales, de cara a una periodización y contextualización someras. En lo que sigue, regresaremos a la primera época de El Mosaico, que representa, como ya lo hemos señalado, un momento fundacional de la literatura nacional.

\section{La revista}

La mayoría de referencias que se hacen sobre El Mosaico abordan casi de manera exclusiva los cuadros de costumbres, que son una parte importante de la producción literaria de esta generación, aunque no la única.

Ciertamente, desde la década de los cuarenta, bajo la influencia de los escritores españoles, el modelo costumbrista ya se encontraba muy difundido en la prensa nacional. Era un género que acompañaba bien la prensa y que tenía sin duda algún éxito. Los cuadros de costumbres, que se hicieron celebres durante todo el siglo XIX en América Latina, abonaban en parte a la tradición

\footnotetext{
${ }^{20}$ A partir de este momento, la cultura se empieza a identificar en Colombia con los sectores de opiniones más conservadoras. Juan María Gutiérrez escribía a Uricoechea sobre la falta que le hacía ver los escritos de sus contradictores políticos, quienes, a su modo de ver tendrían otros modelos literarios: "He leído con gusto el sentido elogio que de su amigo de V. y colaborador Vergara y Vergara hizo del Sr. Don José Manuel Marroquín y me ha sorprendido que un hombre tan entendido no aspirase a ponerse en contacto con otros literatos en Europa que con Trueba, Fernán Caballero y Concience, el novelista en patois. La única tumba gloriosa, ante la que se prosterna como en el santo sepulcro en su peregrinación, es la de Chateaubriand el diplomático restaurador de la monarquía absoluta de Fernando VII en España y de cuya personalidad no ha quedado mas que su aristocrática vanidad y su [...] sexquipedalia verba. [...] Me quedo con la curiosidad de conocer los escritores bogotanos que no tienen las simpatías del tradicionista y no han merecido el honor de ser reimpresos en volúmenes ilustrados con estudios y biografías". Romero, Epistolario, 222-223.
} 
inaugurada desde finales del siglo XVIII con los viajeros ingleses. Abonaban también por supuesto, a la misma construcción de imaginarios nacionales, a la efervescencia de la representación de los pueblos, de sus tradiciones y costumbres, que en la misma transición hacia el siglo XIX se había convertido en una fuente constante de temas literarios.

Sin embargo como se ha señalado, -y los cuadros de costumbres se estudiarán más adelante- al lado de las poesías y escritos costumbristas, los autores le concedieron un lugar importante a otros trabajos, especialmente de carácter histórico (que caían igualmente en una profesión literaria poco especializada), con los que se delinea una de las particularidades más importantes de esta revista en la que se empezó, apoyándose en los documentos de la historia patria, a tratar de construir una memoria colectiva ${ }^{21}$.

Sin mayores dificultades, puede distinguirse en El Mosaico uno de los primeros esfuerzos continuados por crear un vínculo emocional del público lector hacia la nación colombiana, tratando de superar la fragmentación regional, la famosa retórica nacionalista del orgullo republicano que era propia de los discursos políticos, así como el pesimismo sobre el futuro del país. Este esfuerzo, que puede ser señalado como una continuación de la Comisión Corográfica por cuanto con él se adelantó la misma tarea de llevar al público una imagen del país en su parte moral y material, se extiende sin embargo en un plazo más largo y adopta mecanismos diferentes.

La motivación nacionalista se presenta de entrada sin ambigüedades en la revista, que desde un comienzo, busca convocar a un público lector restringido: los hombres de letras (diferenciados de los políticos), sobre quienes recae desde ya la función y responsabilidad social de dar fe de la grandeza nacional:

[...] nuestra patria es totalmente desconocida en su parte material y moral no sólo de los extranjeros que a causa de la ignorancia nos desprecian como a una turba de bárbaros; sino lo que es más triste, es desconocida de sus mismos moradores. Así, pues, en ninguna parte más que en pueblos nacientes como el nuestro, la prensa está llamada a ejercer una alta influencia y a producir ingentes resultados [...] A los que estamos separados de esa lucha enconosa de las pasiones públicas nos toca trabajar con ahínco por hacer conocer el suelo donde recibimos la vida, y donde seguirán viviendo nuestros hijos. A nosotros nos toca el elogio de las grandes acciones, la pintura de nuestros usos y costumbres ${ }^{22}$.

\footnotetext{
${ }^{21}$ Así lo anuncia Vergara en el prospecto del primer número de la revista: “[...] los tesoros inmensos de esta tierra tan rica y tan hermosa, son totalmente desconocidos en la actualidad. Los recuerdos tan originales, tan poéticos de los primitivos habitantes de América se van oscureciendo día por día; la varonil constancia de los compañeros de Colón, los preciosos episodios de la Conquista son casi de todo el mundo ignorados. Y pocos son tal vez los que saben cual fue el aventurero que blandiendo con una mano la espada, echó con la otra las primeras hojas de palma y colgó su armadura donde tres siglos después vino a mecerse su cuna. Y los héroes que con su espíritu y su brazo nos dieron libertad y patria no sólo duermen en ignorada fosa sin mármoles ni bronces, sino que sus hazañas existen apenas en la memoria de los contemporáneos que los han sobrevivido [...]”. El Mosaico, no. 1 (1858)

${ }^{22}$ Ibídem.
} 
El contexto de este llamamiento al patriotismo debe ser evocado: nada más opuesto a la propuesta de Vergara y de los mosaicos, que la cultura eurocéntrica de las elites colombianas del siglo XIX. En efecto, cabe precisar que las elites culturales no han empezado a desarrollar una red de referencias que conduzcan hacia una tradición cultural propia, porque en buena medida, la alta cultura es, propiamente hablando, la cultura europea.

Por esto, si en la década de 1850, y hasta finales del siglo XIX, el libro en Colombia "es todavía por definición un bien importado de Europa" ${ }^{23}$, la revista cumple dos funciones relacionadas. Como primera medida, llevar a la imprenta de manera sistemática obras de escritores colombianos con lo que efectivamente se creaba una bibliografía nacional. Por otra, identificando publicando y publicitando las obras que habían sido escritas por colombianos o por criollos durante la Colonia o los primeros años de República. Obras que se encontraban dispersas, y que venían a demostrar que de hecho, en el país existía una tradición intelectual que no se había hasta ahora sabido orientar ni apoyar convenientemente.

De hecho como decían sus autores, la revista buscaba convertirse ella misma en una "biblioteca nacional", en donde se recogerían de preferencia las obras escritas en castellano por escritores nacionales o hispanoamericanos en diferentes épocas, y donde se centralizarían los esfuerzos dispersos de una elite intelectualmente inquieta. Pero más allá de la misma revista, sus editores buscaron por otros medios estimular la deficiente producción de impresos nacionales. En 1860, cuando esta logró afianzarse y amplió sus actividades editoriales, se imprimieron algunas obras que buscaban igualmente estimular una idea de la importancia cultural de la nación. Entre otras, se editaron una revista dirigida al público especializado europeo, las Contribuciones de la Nueva Granada a las artes y a las ciencias (1860); una colección de cuadros de costumbres de Juan de Dios Restrepo (Emiro Kastos), una colección de poesías nacionales titulada La lira granadina (1860) y un volumen de las obras de Antonio Nariño, el personaje predilecto de José María Vergara.

La misma actitud se refleja fielmente en el catálogo de libros que se vendían en la imprenta de El Mosaico. Allí, entre las novelas, muchas de ellas colombianas, la única traducción que se promocionaba era una de La cabaña del tío $\mathrm{Tom}^{24}$. No se encuentran tampoco, como podría

\footnotetext{
${ }^{23}$ Martínez, El nacionalismo, 109.

${ }^{24}$ En la librería anexa al Mosaico se promocionaba la venta de libros nacionales sobre todo. Asimismo se anunciaban a la venta algunas reproducciones litográficas de personajes de la Nueva Granada, "novelas originales", manuales de ortografía, de retórica y gramática castellana y libros de derecho. La lista de libros en venta, que se enviaban por pedido a los agentes de la revista en el país incluye entre sus títulos principalmente obras literarias, libros de novelas y poesías, así como varios libros de derecho y de gramática, retórica y ortografía:
}

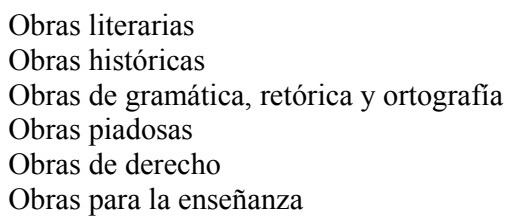

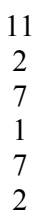


esperarse, las novelas de un Walter Scott que estaban en furor en la época, o las novelas francesas que eran las más vendidas en las librerías de Bogotá ${ }^{25}$.

Asimismo, los editores pusieron desde un principio una cláusula nacionalista: se evitarían al máximo las traducciones, que sólo se publicarían de manera accidental. El énfasis estaba puesto por supuesto en la idea de hacer valorar el castellano como lengua de cultura, con potencialidades de desarrollo y además dueña una dimensión continental. Siguiendo a Herder, Iberoamérica constituía para ellos una sola nación compuesta de varios países.

En realidad, el mismo criterio de promoción de la literatura nacional se puede verificar directamente en la revista, si se toma en cuenta la escasa proporción de artículos tomados del extranjero (ver gráfico 1) y el gran número de colaboradores colombianos ${ }^{26}$. De hecho, de los pocos artículos extranjeros publicados la mayoría eran españoles. Los autores americanos por su parte eran francamente pocos, pero existía la preocupación por atraer su colaboración o en ocasiones su reconocimiento sobre este proyecto que muy probablemente estaba estimulado por la competencia entre las diferentes elites culturales nacionales ${ }^{27}$. En todo caso, El Mosaico atrajo la colaboración de los ecuatorianos Julio Zaldumbide y Juan León Mera y se vendía en Ecuador como en Venezuela. Zaldumbide fue agente de El Mosaico en Quito y Mera, autor de poemas cargados de referencias geográficas y de voces quechuas, se presentó como colaborador regular. Del lado de los peninsulares, hubo en cambio una presencia sorprendente: Antonio de Trueba y Fernán Caballero (Cecilia Böhl de Faber), junto a José Joaquín de Mora fueron de lejos los peninsulares y los extranjeros más publicados, sus novelas aparecían por entregas todas las semanas. Pero escritores españoles hubo bastantes; José Zorrilla, Campoamor, Gabriel García Tassara, José Selgas y Carrasco y el duque de Rivas, se cuentan entre otros muchos. La

Felipe Pérez, Jilma (continuación de los Pizarros); El caballero de la Barba negra; Juan Rodríguez Freyle, El carnero, editado por Felipe Pérez; La biblioteca de señoritas (colección de este periódico); Silveria Espinosa de Rendón, Novena de nuestra señora de la Concepción; Santiago Pérez, Gramática castellana; Bergeron, Aritmética; Manuel Ancízar, Psicología; Cerbeleón Pinzón, Ciencia constitucional;José Antonio de Plaza, Memorias para la historia de la Nueva Granada; Apéndice a la recopilación granadina; Las cruces y el viento (novela); El juego de parejas (novela); Código penal; Ricardo Carrasquilla, Problemas de aritmética; Bernardino Torres Torrente, Sombras y misterios o los embozados; Gregorio Obregón, Metrología; Codazzi, Geografía de la Nueva Granada; Manuel E. Acevedo, Comentario de leyes; Federico Bastiat, Armonías económicas; Felipe Pérez, Análisis del Ecuador; Rienzi, Semana literaria del "neogranadino”; José María Samper, Piezas dramáticas; Alejandro Agudelo, Manual del comerciante; ortografía castellana; La cabaña del Tío Tom; Juan Vicente González, Gramática castellana (séptima edición); Germán Piñeres, Poesías; Prospero Pereira Gamba, Akimen Zaque (novela); Recopilación granadina; Leyes (colecciones correspondientes a 1853, 1854, 1855, 1856 y 1857); Rafael Gutiérrez, Sinónimos castellanos; Francisco O. Barrera, Retórica; José Manuel Marroquín, Ortografía castellana.

${ }^{25}$ Martínez, El nacionalismo.

${ }^{26}$ Dejando de lado una buena cantidad de escritos anónimos o firmados con seudónimos desconocidos, pueden identificarse en los tres primeros años cerca de 90 colaboradores colombianos.

${ }^{27}$ Así lo deja ver la correspondencia de Ezequiel Uricoechea con Juan María Gutiérrez, que muestra como ambos estaban muy al tanto respecto a los avances en la producción bibliográfica en las naciones hispanoamericanas (especialmente en cuanto a los diccionarios o las obras de lingüística). No nos extenderemos sin embargo sobre este asunto. 
idea de una emancipación literaria de España, que arengaban algunos liberales, sería combatida de esta manera por el círculo de El Mosaico.

Es más, dos de los fundadores de El Mosaico, Marroquín y Vergara, manifestarían en más de una oportunidad la necesidad de recuperar el ascendiente español, y en un gesto de diplomacia, más adelante, impulsarían la fundación de las academias correspondientes en América, junto con Miguel Antonio Caro. En efecto, en su viaje a Europa a finales de la década de 1860, Vergara adelantaría la tarea de propiciar un gesto de acercamiento entre los dos lados del Atlántico, mostrándoles el interés que existía en algunos círculos de Bogotá porque se creara una suerte de sede de la academia española en esa ciudad. Los académicos españoles decidieron entonces abrir la puerta a las academias correspondientes americanas, como un gesto de reacercamiento de los dos mundos, pero también erigiendo su autoridad y preeminencia en materia de la lengua.

La idea de unas academias así sujetas a jerarquía, no era para algunos sectores la que mejor reflejaba el espíritu de pueblos que habían luchado arduamente por conseguir su emancipación y soberanía. Y por ello es que las críticas contra una institución semejante no fueron infrecuentes. Fundar esta academia constituía por el contrario, ceder uno de los elementos esenciales de la nacionalidad: la diferencia lingüística. Por otra parte, para muchos, aún la idea de un acercamiento a España era impensable, ya que el modelo español era considerado la fuente del retraso de los países latinoamericanos. Así por lo menos lo reflejaban las agudas críticas que formulara desde Buenos Aires Juan María Gutiérrez. Pese a ser filólogo, corresponsal de Uricoechea, Gutiérrez redactó una carta que se hizo pública y que circuló en varios periódicos de Latinoamérica suscitando escándalo, donde manifestaba su rechazo a la invitación formal que le hacía la academia española de fundar una academia correspondiente en Buenos Aires. Gutiérrez sostenía, entre otras cosas, que mejor sería seguir el ejemplo de los países de habla inglesa, que habían dejado a la lengua libre de las amarras de una institución investida de poderes de censura. Homologaba así el espíritu español a la Inquisición y al proteccionismo. Sugería, además, que el español de Argentina debería seguir el curso propio que ya había iniciado y que lo llevaría a constituirse en una lengua propiamente nacional. La eventual incomunicación entre los países iberoamericanos, que era uno de los argumentos en pro de la unificación de las academias, no sería para Gutiérrez, más que un paso necesario en la formación nacional argentina. El espíritu de esta posición, sin embargo, no pasa de un mero acto deliberadamente polémico, pues buena parte de la obra del argentino propendió por el contrario por una unidad de las letras iberoamericanas o al menos latinoamericanas. Y más todavía, argentinos y colombianos todavía se comunican, con algunos tropiezos, es cierto, en el mismo idioma. 


\section{Gráfico 1}

Distribución de los artículos de $E l$ Mosaico según materias y por origen. Años 1859, 1860, 1865

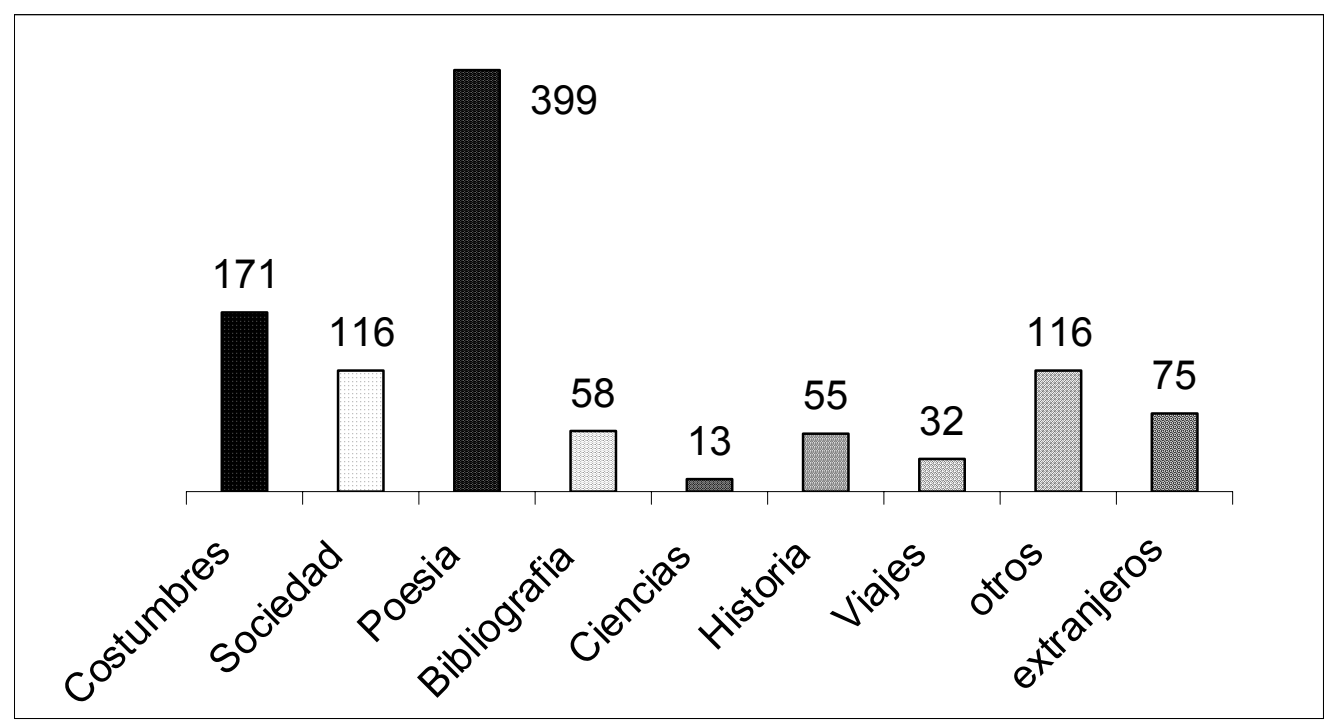

\section{Historiadores, biógrafos y bibliógrafos}

Entre las preocupaciones de El Mosaico uno de los temas que llaman particularmente la atención, es la fuerza que toma el estudio de las antigüedades nacionales, y en especial la escritura de biografías y la creación de catálogos bibliográficos, hasta entonces inexistentes. Estos serían la base para construir el panteón de héroes de la Nueva Granada, así como la fuente de los primeros trabajos sobre el genio "nacional".

Sin contar una gran cantidad de poesías que se editaron, muchas de ellas dedicadas a las costumbres, (sobre la chicha, el tabaco, etc.), la naturaleza (el salto del Tequendama, el Guadalupe en Antioquia, etc.), la colección sistemática de obras nacionales, y los trabajos históricos fueron unas de las preocupaciones centrales de los mosaicos (bibliografía e historia en el gráfico 1), en medio de una polifacética búsqueda del "patrimonio nacional".

Las colecciones bibliográficas fueron en especial el trabajo de tres autores, que se consideraban a sí mismos herederos de la afición del coronel Anselmo Pineda, quien había guardado escrupulosamente durante décadas una gran cantidad de documentos, hojas, folletos e impresos 
de carácter histórico, que donaría a la nación en $1852^{28}$. Se trataba de Ezequiel Uricoechea (1884-1880), quien traía de Europa, además de su libro sobre las Antigüedades neogranadinas (1854) (proyecto que seguía la línea de los Merimés europeos), otras ideas, como la edición de una mapoteca colombiana (1860), y la creación de una colección filológica sobre las lenguas aborígenes; José María Vergara (1836-1872), director de la revista, que iría a construir con base en el patrimonio bibliográfico recuperado su Historia de la literatura en la Nueva Granada (1868); y por último José María Quijano Otero (1836-1883), dueño de la más grande colección de libros antiguos de los tres bibliógrafos y autor de un Compendio de historia patria, para uso de las escuelas primarias $(1874)^{29}$.

En El Mosaico, Vergara llegó a publicar algunos avances de su trabajo bibliográfico. Estos constituían para él las primeras muestras de un trabajo sistemático, de largo alcance, con el que aspiraba a mostrar el "desarrollo del espíritu en la Nueva Granada"30, a través de la evolución de la poesía y la novela particularmente. Entonces, su aspiración era encontrar apoyo en el gobierno para crear una "Biblioteca Neogranadina", una obra que calificaba de monumental y que estaría dividida en cuatro secciones: historia, viajes, filología y documentos oficiales. Pero el proyecto fue rechazado en 1864 por el congreso, no obstante los empeños de Vergara en su revista por defender la utilidad de ese conocimiento erudito, que según sus quejas, se practicaba en la más grande soledad ${ }^{31}$.

A pesar de todo, y sin apoyo institucional, la investigación bibliográfica daría sus frutos más tarde, con la publicación en 1867 de la Historia de la literatura en Nueva Granada, donde Vergara criticaba la historiografía liberal. Esta obra la comentaremos más adelante. Por otra parte otro de los bibliógrafos de El Mosaico, Ezequiel Uricoechea, ya de regreso a Europa dio a conocer los resultados de su indagación bibliográfica en la Revista Latinoamericana, una

\footnotetext{
${ }^{28}$ Con la donación de Pineda a la nación se creó una Biblioteca de Obras Nacionales en la Biblioteca Nacional (Decreto del 18 de agosto de 1852). A esta colección se sumaron pronto las de otros estudiosos de las "antigüedades nacionales": el coronel Joaquín Acosta y Manuel Ancízar.

${ }^{29}$ En Popayán, Eladio Vergara y Vergara autor de un poema épico titulado la Guerra de Neo-Granada (aparecido en La Matricaria, la primera revista que editó José María Vergara en 1855) poseía otra colección bibliográfica.

${ }^{30}$ El Mosaico, no. 47 (26/11/1859). El artículo lleva por título "Bibliografía neogranadina". Allí Vergara afirmaba que él había comenzado a recoger sus materiales hacia 1854 en Popayán. La primacía se la disputaba Ezequiel Uricoechea, que llegó de Europa en 1857.

31 "Tales datos, impertinentes para los conocedores de ellos, curiosos y útiles para los extraños, no tienen más mérito de nuestra parte, que la voluntad que empleamos en asegurar por la prensa la constancia de estos detalles, los cuales, unidos a otros y otros, vienen a formar la parte documentada de la historia del desarrollo del espíritu en la Nueva Granada. Si esto no es una creación, no es tampoco un trabajo despreciable para el que lo emprende. Tan pocas como parecen las líneas que vamos a escribir, son, sin embargo, hijas de una investigación prolija; pues en este país el bibliógrafo se instruye de la existencia de las obras publicadas por instinto, y no porque haya quien conteste a las averiguaciones que hace [...]". "Bibliografía neo-granadina. Catalogo de las obras literarias originales publicadas en la Nueva Granada (parte lírica y dramática)", El Mosaico, no. 47 (26/11/ 1959) y no. 49 (10/12/1959). En la lista se relacionan 83 impresos. En el mismo año Vergara publicó también un catálogo de novelas neogranadinas, aparecido en El Mosaico, I, no. 18, (25/04 /1859).
} 
publicación comparable a El Mosaico, que a nivel latinoamericano estaba empeñada en dar a conocer la cultura americana en París ${ }^{32}$.

En El Mosaico, se editaron siguiendo la misma línea historicista algunos documentos relativos a la guerra de Independencia, la historia patria y a la Expedición Botánica, así como algunas estadísticas curiosas ${ }^{33}$. Además, se presentaron otros documentos antiguos referidos a la Colonia, y se hizo mucho eco de la primera edición de El Carnero que preparó Felipe Pérez ${ }^{34}$.

Asimismo se advierte un gran número de biografías. Uricoechea, contribuyó con las de Mariano E. Rivero y Francisco Javier Matiz, miembros respectivamente de la Comisión Zea y de la Expedición Botánica. José Joaquín Ortíz escribió la biografía de Juan María Céspedes y José Manuel Marroquín la de su antepasado Francisco Antonio Moreno y Escandón. Vergara, más sistemático, se decidió a inaugurar una sección biográfica de literatos neogranadinos y otra de notabilidades colombianas. Allí se reseñaron en los primeros años las vidas de Pedro Fernández Madrid, Juan de Herrera y José Angel Manrique. Como biógrafo Vergara continuará escribiendo en La Caridad (1864-1878) ${ }^{35}$ donde publicaba una "serie" de biografías de neogranadinos ilustres.

Cabe destacar que al tiempo en que aumenta la preocupación bibliográfica y biográfica, se empieza a advertir una nueva visión del documento histórico, lo que también implicará llevar a cabo una primera revisión de la historia patria. El contexto de esta valorización está dado por la reedición en 1859 de la Historia de la Revolución en Nueva Granada de José Manuel Restrepo, que vino acompañada de cierta polémica en la que se planteaba el problema de la verdad histórica. Vergara manifestó su desacuerdo con esa versión de la historia, porque consideraba que siendo escrita por un testigo excepcional, sin apoyo de documentos, allí se encontraba latente el mismo sectarismo que dividía aún al país. Para el autor de la primera historia de la literatura colombiana, la historia de Restrepo parecía más bien un alegato:

Nos ha parecido que los años han retrogradado, que estamos aún en 1830 y 1832 : nos ha parecido [...] que hemos asistimos a las luchas de Santander contra sus

\footnotetext{
${ }^{32}$ La revista tuvo una breve existencia en 1874. Su director, Adriano Páez, había creado antes una revista cultural para el Estado de Santander, inspirado por El Mosaico y también contribuyó con esta revista como agente y como colaborador. Martínez, El nacionalismo; Romero, Epistolario, 53.

${ }^{33}$ Los documentos históricos son los siguientes: Relación de oficiales fusilados por Santander; Lista de implicados en la noche septembrina; Lista de fusilados por Morillo el 6 de agosto de 1816, Lista de individuos que ofrecieron mantener soldados para la guerra con Calzada; Relación de individuos que salieron de Bogotá a capitular con los comuneros del Socorro; Real Cédula separando el virreinato de la Nueva Granada de las provincias de Guyana, Maracaibo e islas de Trinidad y Margarita; Real cédula separando del gobierno de Caracas la ciudad de Trujillo; Real cédula de la Expedición Botánica.

${ }^{34}$ En 1859, Felipe Pérez editó por primera vez una versión del Carnero, una crónica de los escándalos sociales de los primeros cien años de la colonia en Bogotá, que hasta entonces venía circulando manuscrita de mano en mano en diferentes versiones.

${ }^{35} \mathrm{La}$ Caridad, una revista que permanece en el círculo de conservadores, era dirigida por José Joaquín Ortíz. Antonio Gómez Restrepo, Historia de la literatura colombiana (Bogotá: Ministerio de Educación Nacional, 1945-46).
} 
rivales; nada ha cambiado, los odios de entonces, las emulaciones de aquellos tiempos, todo es igual $[\ldots]^{36}$.

Vergara anteponía pues a la autoridad del testimonio la del documento y sostenía que las injurias que caían sobre personajes como Antonio Nariño, Pedro Fernández Madrid y Andrés Bello, no solamente eran infundadas, sino que se trataba de hombres que debían ser considerados como "glorias nacionales" y él se proponía demostrarlo:

Por fortuna, los documentos que desmienten a Nariño, Bello y Madrid, existen en todos los archivos particulares y públicos [...] por fortuna, también ha llegado la Historia [de Restrepo] cuando estábamos juntando materiales para imprimir las Obras de Nariño [...] y cuando estabamos escribiendo la obra de Madrid. Nuestros esfuerzos no serán los que los vindiquen: serán sus obras y la exposición sincera de sus vidas ${ }^{37}$.

De nuevo, lo que se manifiesta en el centro del debate es la preocupación por la creación de un panteón de héroes nacionales. En este aspecto, algunas naciones europeas se mostraban ejemplares. Es lo que veremos a continuación al comprobar la repercusión que tuvo en la revista un personaje de la nueva mitología nacionalista británica, hoy olvidado pero que durante buena parte del siglo XIX estuvo en boga: el bardo Ossian.

\section{Ossian}

A pesar de que se hacía eco de las noticias del exterior sobre los acontecimientos en el mundo de las letras, por ejemplo de la muerte de Quintana, de Humboldt, de Washington Irving, del venezolano José María Baralt, tomadas del Correo de Ultramar, que dirigía en París José María Torres Caicedo, del Courier de l'Europe o del Eco Hispanoamericano, como se ha dicho las traducciones fueron pocas. Muy poco de Pope, algo de Goldsmith, un par de artículos dedicados a Lamartine, algunas imitaciones de Víctor Hugo y nada de Walter Scott es lo que se puede encontrar en los primeros años.

Sin embargo, sorprende encontrar un par de traducciones que despertaron un gran interés y que fueron hechas con mucho entusiasmo patriótico por parte de José Joaquín Borda y Lorenzo María Lleras: los cantos del bardo Ossian. Recogidos de la tradición oral escocesa y traducidas al inglés por McPherson en la segunda mitad del siglo XVIII, los cantos de Ossian, aparecidos por primera vez en Londres en 1761 bajo el título Fingal, an ancient epic poem, in 6 books, together with several other poems, composed by Ossian, the son of Fingal; translated from the gaelic language by James McPherson, seguidos de Temora, cumplieron, como lo señala Anne Marie Thiesse ${ }^{38}$ una de las tareas primordiales previas a la construcción de las naciones modernas. Estas epopeyas supuestamente recogidas de la tradición popular manifiestan, además

\footnotetext{
36 "Historia de Colombia por el Señor J. M. Restrepo", El Mosaico, no. 33 (13/08/1859).

${ }^{37}$ El Mosaico, no. 33 (13/08/1859).

${ }^{38}$ Thiesse, La création des identités.
} 
de una revolución estética producida desde mediados del siglo XVIII, en la que se comprometieron las elites intelectuales europeas, una redefinición de las relaciones entre lo universal y lo particular, necesaria para la construcción de las culturas nacionales.

Los cantos de Ossian, que no fueron los únicos retoños de esta "campaña" cultural, puesto que en Europa se produjeron hacia la misma época algún número de estas epopeyas escritas en versos clásicos, si lograron convertirse en un modelo tan prestigioso como el de la epopeya homérica, en donde se narraba la lucha heroica de la nación celta en la defensa de su soberanía contra la expansión romana en el siglo III. A pesar de haber sido objeto de una polémica sobre su autenticidad, los cantos de Ossian fueron celebrados en toda Europa, donde empezaban a descubrirse un poco por todas partes antiguos manuscritos medievales o leyendas populares que iban siendo convertidos en monumentos culturales necesarios para la fundación de las culturas nacionales.

En Hispanoamérica a comienzos del siglo XIX, los cantos de Ossian fueron conocidos como lo demuestra el hecho de que fueron traducidos por José María Heredia, o que Francisco Antonio Ulloa, fusilado en Bogotá por las tropas pacificadoras de Morillo, haya dejado manuscritas unas imitaciones del bardo celta ${ }^{39}$. Además, en la misma dirección de recuperación de los mitos fundadores de la nación se pueden señalar los trabajos de Andrés Bello sobre el Mío Cid. Este autor, como lo recuerda Pedro Henríquez Ureña, tomaba como referencia para la escritura de su Silva americana no sólo a Virgilio y a Horacio, sino también a Los Nibelungos, el monumento literario que se había levantado a la cultura alemana en $1757^{40}$.

El entusiasta descubrimiento de la epopeya ossianesca, hecho por José Joaquín Borda ${ }^{41}$ casi un siglo después de aparecida la primera edición inglesa de Temora, daba un impulso a la literatura nacional.

En la década de los sesenta, a Borda lo que menos le interesaba era la polémica sobre la autenticidad de la epopeya, que había descubierto al parecer en una traducción francesa. Si McPherson había realmente sido fiel a la tradición popular o si había inventado a Ossian, que era lo que inquietaba a muchos críticos y filólogos, no era un punto sobre el que quería volver. Lo que le fascinaba del bardo era al mismo tiempo su antigüedad y su incré́ble modernidad ${ }^{42}$. Por esto, gracias al sentimiento de patriotismo que inspiraba estos poemas, Borda consideraba

\footnotetext{
${ }^{39}$ José María Vergara y Vergara, Historia de la literatura en Nueva Granada. 2 tomos (Bogotá: Biblioteca Banco Popular, 1974); El Mosaico, no. 46 (24/11/1860).

${ }^{40}$ Pedro Henríquez Ureña, Las corrientes literarias en la América hispánica (México: Fondo de Cultura económica, 1949).

${ }^{41}$ El Mosaico, no. $46(24 / 11 / 1860)$.

${ }^{42}$ El primer artículo de Borda sobre McPherson "Ossian", empieza con una cita de las Confidencias de Lamartine, en la que se muestra una irresistible voluntad de credulidad en la exitencia del bardo: "Ossian est certainement une des palettes où mon imagination à broyé le plus de couleur, et qui a laissé le plus de ses teintes sur les faibles ébauches que j'ai tracé depuis. C'est l'Eschyle de nos temps tenebreux. Des érudits curieux ont prétendu et prétendent encore qu'il n'a jamais existé ni écrit, que ses poemes sont une supercherie de McPherson. J'aimerais autant dire que Salvator Rosa a inventé la nature".
} 
que sus cantos debían darse a conocer en la lengua española, para en seguida ser tomados como modelo literario. "La religión de Ossian", como la llamaba Borda, se acordaba bien con la voluntad de erigir un santoral laico de héroes nacionales. Ella misma no sólo podía servir como motor para crear y promover el amor nacional sino que también constituía un ejemplo de retórica nacionalista, por ejemplo para los himnos patrióticos. La nueva religión (que es toda devoción a la nación moderna), ofrece un paraíso de gloria, un palacio errante, a quienes están dispuestos a darlo todo por la patria:

Los dioses de Roma y Grecia han envejecido ya: los fulgores del Olimpo se han desvanecido ante la luz celestial del Cristianismo; y aquella monstruosa cadena de dioses y semidioses no serán ya los númenes del poeta: aquella religión en vez de recibir el incienso que le han ofrecido los clásicos, será mirada en adelante como lo supremo del ridículo. Empero no sucederá lo mismo con la religión de Ossian. Él, que sólo vivía para la gloria; él, que en cada uno de sus compatriotas miraba un héroe ardiendo en amor por la Libertad y por la Patria, divisa, más allá de la muerte, las nubes convertidas en un palacio errante, a donde vuelan los virtuosos y los valientes, aquellos para servir de ejemplo a los que quedan en el mundo, y estos para cambiar en gloria duradera sus cicatrices y sus victorias [...] El ejército que levanta ya los aceros en defensa de la Patria insultada, eleva los ojos y descubre entre esplendores la falange de héroes sus antepasados, que derramando su sangre en los campos de batalla, acabaron de inmortalizar una vida de honor y de gloria ${ }^{43}$.

Es interesante comprobar cómo la descripción de los cantos, de la rusticidad propia del tiempo en que fueron escritos, fascinan a Borda, quien se detiene además en el mismo tono melancólico de los versos, en una descripción de lo que hoy llamaríamos las "estrategias narrativas", y espera que se las imiten, en el campo formal y "filosófico", para bien de la literatura nacional:

[...] es preciso que ellas [las poesías de Ossian] toquen y enciendan los corazones jóvenes; es preciso que sobre ellas se formen cantos en que brillen las hazañas de nuestros guerreros o las bellezas colosales de nuestra patria ${ }^{44}$.

Las traducciones de Borda las continuó al menos de manera inmediata Lorenzo María Lleras, quien seguirá escribiendo sobre Ossian en El Mosaico con la misma fascinación, pero mejor informado. Así Lleras desmentirá las pretensiones de Borda de ser el descubridor de estas poesías para el castellano, señalando la existencia de una edición de sus obras hecha por Nicasio Gallegos, de las ya citadas traducciones de José María Heredia y de unas imitaciones de José de Espronceda.

Lo que estas traducciones evidencian, es en últimas el entusiasmo por un modelo de nación, el modelo europeo, basado en la unidad de lengua, en la homogeneidad racial y en el origen compartido, que estos escritores no podrán trasponer impunemente en Colombia. Más bien, la

\footnotetext{
${ }^{43}$ El Mosaico, no. 8 (25/02/1860).

${ }^{44}$ Ibídem.
} 
epopeya ossianesca hacía a estos intelectuales advertir la ausencia de unos ancestros comunes; delataba un vacío en el proceso de mimesis con la idea de nación europea.

Es pues ahora que conviene aclarar la representación de la nación colombiana que se hacían los escritores de El Mosaico, pero antes, conviene abrir un paréntesis donde trataremos de demarcar la amplitud de la difusión de la revista.

\section{Los lectores y los agentes}

¿A quienes se dirigía la revista? No parece arbitrario afirmar que por sus contenidos, ella se dirigía a unas elites letradas a las que a su vez trataba de formar. Es difícil sin embargo ir muy lejos en las afirmaciones, puesto que la información disponible sobre los hábitos de lectura no permite hacer muchas comparaciones en lo que respecta a este periodo. Pero veamos las cifras parciales con las que se cuenta. Con respecto al público, para 1860, los redactores mantenían correspondencia con un poco más de 50 agentes repartidos en diferentes municipios y localidades del país. Ellos estaban encargados de conseguir los suscriptores y eran los intermediarios para los encargos de libros que se encontraban a la venta en El Mosaico. En el mismo año, de acuerdo a una lista publicada en la revista, había cerca de 400 suscriptores en el país, de los cuales el $30 \%$ correspondía a Bogotá (cerca de 120 suscriptores). Si se toma como criterio el número de abonados, no resulta nada comprometedor afirmar que la publicación se dirigía a una minoría culta, aunque siempre es difícil estimar el alcance real de la publicación. Por ejemplo, el listado de los suscriptores no da cuenta de los ejemplares que se vendían sueltos en la agencia de Bogotá. Además, era una constante que un solo ejemplar fuera leído por más de una persona. Por ejemplo, refiriéndose a la costumbre de leer el periódico "de gorra", como antagónica a la evolución del periodismo, se escribió un artículo firmado con el seudónimo de Eudoro, en la época de decadencia de la revista, cuando Felipe Pérez y el grupo de "progresistas" asumieron la dirección

[...] nadie quiere suscribirse. Los lectores saben arreglarse de tal modo que la lectura les salga gratis, y poco les importa que el empresario tenga invertido un capital improductivo [...] si hay en la población unos cuantos suscriptores, sus periódicos van rodando de mano en mano, mientras que los otros quedan bajo el mostrador del agente ${ }^{45}$.

También era posible que se diera el caso de una lectura en voz alta, por lo que las cifras, aunque constituyen un índice valioso, deben ser miradas con cuidado. En cualquier caso, una rápida mirada a la distribución de los suscriptores de la revista de acuerdo a las regiones puede ser útil, no sólo porque permite descifrar el público al que se dirigía la revista, sino su alcance en el propósito de crear un vínculo entre los escritores nacionales, y muy importante, entre la misma sociedad.

\footnotetext{
45 “La gorra en el periodismo", El Mosaico, no. 20 (10/06/1865).
} 
Gráfico 2

Distribución de los suscriptores de El Mosaico por Estados

1860

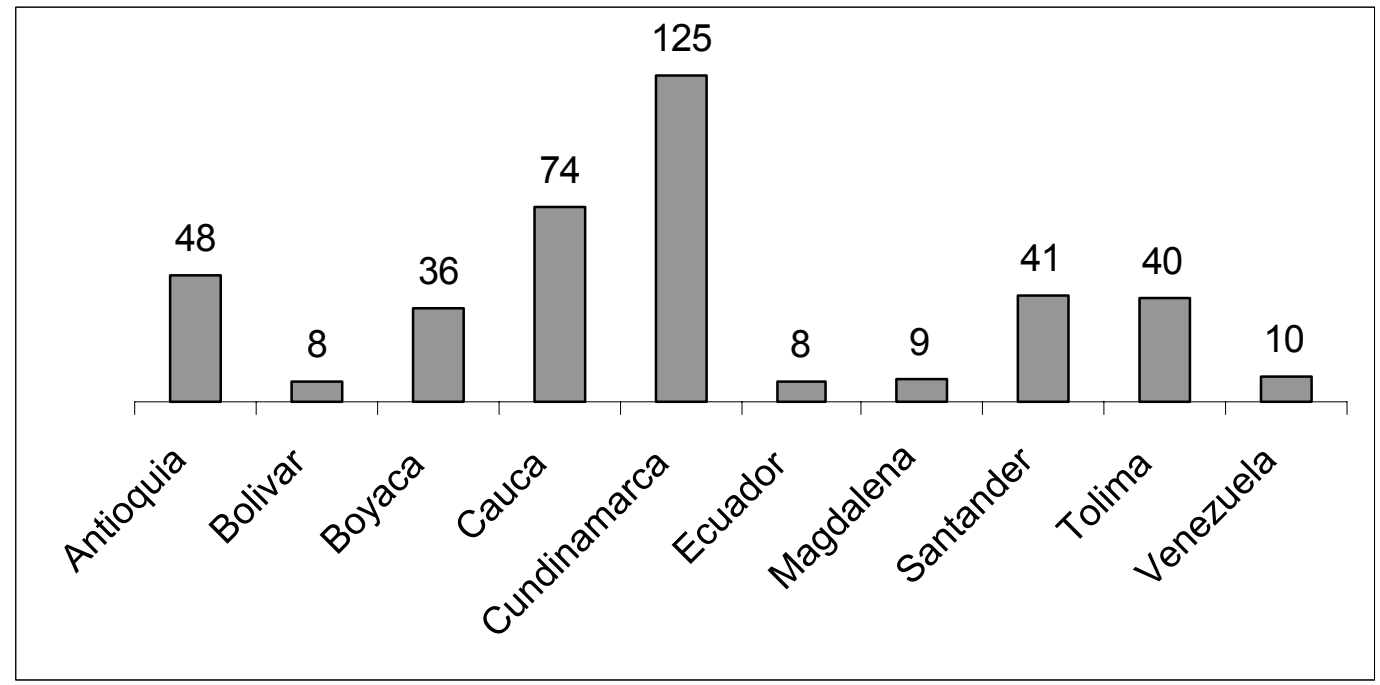

En este gráfico, donde se describe la distribución de la revista por estados, se toma en cuenta la división política vigente en 1860, la que se vino configurando desde 1855 con la creación de los estados soberanos y que ratificó el congreso en la Constitución de la Confederación Granadina de 1858. Con base en esta división, es notoria la poca circulación de la revista en los estados del Caribe, Magdalena y Bolívar, apenas semejante a la circulación en Ecuador y Venezuela, y la nula red de distribución en el Estado de Panamá, mientras que en el interior del país ésta fue homogénea, más aún si se tiene en cuenta que las cifras de Cundinamarca y del Cauca incluyen los suscriptores de Bogotá (117), Popayán (12) y Pasto (11). Estas ciudades, junto con El Socorro, en Santander, fueron las que aportaron un mayor número de suscriptores. 
Tabla 2

Agentes de El Mosaico por Municipios y Estados 1860

\begin{tabular}{|l|l|l|l|l|}
\hline Apellido & Nombre & Estado & Ciudad & $\begin{array}{l}\text { No. } \\
\text { Ejemplares }\end{array}$ \\
\hline Angel & Benicio & Antioquia & Rionegro & 2 \\
\hline Restrepo & Juan P. & Antioquia & Abejorral & 3 \\
\hline Aguilar & Antonio & Antioquia & Amalfi & 3 \\
\hline Pérez Pagola & Braulio & Antioquia & Peñol & 3 \\
\hline Trujillo & Hermenegildo & Antioquia & Angostura & 4 \\
\hline Villegas & Eusebio & Antioquia & Manizales & 4 \\
\hline Mesa & Rafael & Antioquia & Antioquia & 5 \\
\hline Estrada & Faustino & Antioquia & Aguadas & 5 \\
\hline Herrera & Daniel & Antioquia & Zaragoza & 5 \\
\hline Trujillo Restrepo y Cía & & Antioquia & Medellín & 6 \\
\hline Saravia & Luis María & Antioquia & Rionegro & 8 \\
\hline Tayara & Blas J. & Bolívar & Corozal & 4 \\
\hline Rodríguez & Manuel S. & Bolívar & Mompós & 4 \\
\hline Murillo & Pedro & Boyacá & Chámeza & 2 \\
\hline Estrada & Leonidas & Boyacá & Puentenacional & 2 \\
\hline Rojas & Antonio & Boyacá & Leyva & 3 \\
\hline Gómez & Tomas & Boyacá & Moniquirá & 3 \\
\hline Barrera & Juan N. & Boyacá & Sogamoso & 3 \\
\hline Casas Rojas & Joaquín & Boyacá & Chiquinquirá & 4 \\
\hline Vargas & Ignacio & Boyacá & Moreno & 4 \\
\hline Calderón & Aristides & Boyacá & Soatá & 6 \\
\hline Barrera & Antonio & Boyacá & Tunja & 9 \\
\hline Nieto & Gabriel & Cauca & Palmira & 2 \\
\hline Arboleda & Manuel E. & Cauca & Quilichao & 3 \\
\hline Salcedo & Prospero & Cauca & Buga & 4 \\
\hline Franqui & Antonio & Cauca & Cartago & 4 \\
\hline Prado Concha & Rafael & Cauca & Palmira & 4 \\
\hline Arrunategni & Ricardo & Cauca & Quibdo & 4 \\
\hline Quintero P. & Ramón & Cauca & Roldanillo & 4 \\
\hline Girón & Pedro & Cauca & Tuluá & 4 \\
\hline Mallarino & Vicente H. & Cauca & Cali & 5 \\
\hline Mosquera & Alejandro & Cauca & Nóvita & 5 \\
\hline Ormaza & Nicolás & Cauca & Nóvita & 5 \\
\hline De la Peña & Antonio L. & Cauca & Buenaventura & 7 \\
\hline Vergara & Eladio & Cauca & Popayán & 11 \\
\hline & & & & \\
\hline
\end{tabular}




\begin{tabular}{|l|l|l|l|l|}
\hline Apellido & Nombre & Estado & Ciudad & $\begin{array}{l}\text { No. } \\
\text { Ejemplares }\end{array}$ \\
\hline Torres & Abel & Cauca & Pasto & 12 \\
\hline Anzola & Ruperto & Cundinamarca & La Palma & 2 \\
\hline Asencio & José María & Cundinamarca & Funza & 3 \\
\hline Clavijo & Ramón & Cundinamarca & Ubaté & 3 \\
\hline Guarín & José David & Cundinamarca & Bogotá & 117 \\
\hline Pereira Gamba & Benjamin & Ecuador & Loja & 4 \\
\hline Cevallos & Pedro Fermín & Ecuador & Quito & 4 \\
\hline Woigt & Aristides & Magdalena & Barranquilla & 4 \\
\hline Salas & Moisés & Magdalena & Riohacha & 5 \\
\hline Peñafort & Ramón & Santander & Vélez & 2 \\
\hline Ramírez F. & José María & Santander & Cúcuta & 4 \\
\hline Bermúdez & Baldomero & Santander & Piedecuesta & 4 \\
\hline Villar & Crisóstomo & Santander & San Gil & 4 \\
\hline Jácome & José D. & Santander & Ocaña & 6 \\
\hline Páez & Adriano & Santander & Socorro & 21 \\
\hline Alvarez & José María & Tolima & Gigante & 2 \\
\hline Troncoso & Pedro M. & Tolima & Piedras & 2 \\
\hline Maz & Joaquín & Tolima & Timaná & 2 \\
\hline Monsalve & J. Manuel & Tolima & Espinal & 3 \\
\hline Barón & Leopoldo & Tolima & Guamo & 3 \\
\hline Torres Torrente & Bernardino & Tolima & Ibagué & 3 \\
\hline Fernández & José & Tolima & La Plata & 3 \\
\hline Barrios & Marcelo & Tolima & Purificación & 3 \\
\hline Trujillo & José Ignacio & Tolima & Villavieja & 3 \\
\hline Blanco & J. Trinidad & Tolima & Ambalema & 4 \\
\hline Murillo & Francisco & Tolima & Honda & 4 \\
\hline Larota & José María & Tolima & Lérida & 4 \\
\hline Alvarez & Salvador María & Tolima & Neiva & 4 \\
\hline López & Belisario & Venezuela & Táchira & 4 \\
\hline Briceño & Ramón & Venezuela & Trujillo & 6 \\
\hline & & & & \\
\hline
\end{tabular}

Fuente: El Mosaico, s.n. (mayo de 1860).

Por otra parte en la tabla anterior sobre los agentes de la revista, llama especialmente la atención el alto número de suscripciones que se enviaban al municipio del Socorro, 21 en total. Pero no se trata de una sorpresa, si se tiene en cuenta que Renán Silva ya destacó la alta proporción de alfabetismo de esta provincia con respecto al resto del país en uno de sus trabajos sobre la Universidad colonial, en el que además resaltaba la mayor afluencia de estudiantes santandereanos a la Universidad en comparación con los de otras regiones. Por otra parte, si miramos este caso de cerca tomando como base las cifras de las elecciones presidenciales de 
1856, las únicas del siglo XIX en que fue convocado el sufragio universal de varones siguiendo lo establecido por la constitución de $1853^{46}$, se tiene que al Socorro se enviaron en 1860 un poco menos de dos ejemplares de El Mosaico por cada cien votantes (sobre un total de 1075 votantes) $)^{47}$.

En todo caso la cifra es relativamente elevada si se tiene en cuenta el promedio nacional, y es un indicativo a retener. Para la opinión, el alto o bajo consumo de esta publicación era visto en términos de la "nobleza" de las ciudades; o mejor, estaba relacionado con un estatus cultural, en el que estaban en juego el buen gusto y nombre de la ciudad; y a través suyo el de las "señoritas bonitas y los jóvenes inteligentes". En la correspondencia con Ezequiel Guzmán, agente del municipio de Guaduas, José David Guarín, después de anunciarle el envío de unas láminas litografiadas que se ofrecían a quienes tomaran una suscripción anual ${ }^{48}$, se quejaba de la escasez de suscripciones en estos términos: "La patria de Acosta y de tantas muchachas bonitas y de tantos jóvenes inteligentes da pocos suscriptores a El Mosaico, ¿qué es esto?”49.

Las relaciones con los agentes aparecen tímidamente reflejadas en la sección de correspondencia que en breves renglones ocupaba la última página de la revista. Gracias a esto nos enteramos por ejemplo de una relación estrecha con el agente de Popayán, Eladio Vergara, quien a su vez dirigía otra revista literaria: El Albor, de la que sin embargo se tienen pocas noticias. Otro tanto ocurre con Bernardino Torres Torrente, autor de una novela sobre la vida estudiantil en Bogotá y director del colegio San Simón de Ibagué.

Está por hacerse una prosopografía de esta población, vagamente definida como una elite intelectual. En todo caso, el movimiento cultural de la época sin duda parece, a juzgar por estos indicios, mucho más animado de lo que en un principio se puede suponer.

Por el momento, regresemos al plano de los discursos y de las representaciones que ya hemos venido desglosando.

\section{Los cuadros de costumbres nacionales}

En El Mosaico el nacionalismo articula y da sentido a sus múltiples manifestaciones. En torno a la publicación, los asiduos de la tertulia coincidieron en la voluntad de consagrarse a fabricar una cultura nacional, en parte como contestación al afrancesamiento y a la influencia inglesa,

\footnotetext{
${ }^{46}$ David Bushnell, Colombia, una nación a pesar de sí misma (Bogotá: Planeta, 1996).

${ }^{47}$ Bushnell en Urrutia y Arrubla, Compendio, estima que este número de votantes corresponde al $33 \%$ de la población teóricamente hábil para votar, es decir mayores de 21 años o menores pero casados La provincia del Socorro muestra aún para la década de 1860 una actividad cultural significativa. Así, fuera de que en este municipio se vendían relativamente mas ejemplares de El Mosaico, es de destacar que sus agentes promovieron una revista literaria dedicada "a la juventud del Estado de Santander". En ésta, que se llamó "El Repertorio" estaban comprometidos Prudencio Rei y José Gregorio y Adriano Páez.

${ }^{48}$ Las litografías que se anunciaban en la correspondencia eran "el retrato de Matis [...] la familia de Juan Miguel (¿?) [...] y la ciénaga de Buga". "Correspondencia”, El Mosaico, no. 21 (30/05/1860).

${ }^{49}$ Ibídem.
} 
acercándose como lo hemos señalado al documento e incluso en algunos casos a la madre patria. Por cierto, estos escritores se dedicaron también al estudio de las costumbres populares y se encuentra en algunos de ellos unas primeras evocaciones positivas sobre el pasado colonial. En este marco, como forma de representación de la nación, de la idiosincrasia del pueblo y de los diferentes componentes típicos y hasta cierto punto específicos de la sociedad urbana y campesina nacional, se recurrió a los cuadros de costumbres.

Según su definición, los cuadros de costumbres eran representaciones de la vida social, inspiradas o "copiadas" del natural. Sin embargo además de cumplir una función de representar al pueblo, se les solía atribuir otra función de tipo moral: la misma narración de los hechos debía dejar al descubierto vicios y virtudes y apuntar a la corrección de hábitos perjudiciales y anticuados. Enfocando el vasto mundo social, cambiante y en buena parte desconocido, estos cuadros de costumbres iban a completar luego en varios tomos un museo, o una galería de tipos y usos y costumbres nacionales, como se había hecho en Madrid, donde había sido editada en 1843 una colección titulada "Los españoles pintados por ellos mismos". En Colombia, donde se emulaba la tendencia, los dos primeros tomos de seis que completaron el "Museo de cuadros de costumbres y variedades" fueron editados en la imprenta de El Mosaico en 1866.

El costumbrismo no es el primer género literario nacional: es un género literario transnacional, que se expande en toda Hispanoamérica en el momento en que se están formando las naciones. Estrechamente relacionados con la literatura de viajes y con la pintura costumbrista, ya en la década de los cuarenta los cuadros de costumbres constituían un género muy practicado en toda América Latina ${ }^{50}$. En cierta forma, puesto que requerían de una observación metódica del vestido, de las costumbres y de las tradiciones, pueden ser asimilados al folclorismo. En Colombia se conocen los grandes trazos de la trayectoria de este género: los primeros cuadros que se conocen son los que Rufino Cuervo publicó en El Argos, un semanario fundado en 1837 en Bogotá por Lino de Pombo y Juan de Dios Aranzazu. Después se los encuentra en El Observador (1839) y en El Duende (1846-1847) semanario dirigido por José Caicedo y Rojas e inspirado en El Duende Satírico, que dirigió Mariano José de Larra en Madrid en 1828. En la década de los 50, se los publica en El Museo (1849) y en El Pasatiempo (1850), acompañados con reproducciones de las acuarelas del pintor costumbrista Ramón Torres Méndez ${ }^{51}$. También aparecieron algunos en El Trovador (1850), de Caicedo Rojas y José María Samper y en $E l$ Neogranadino (1849-1851), donde se publicaba por entregas la Peregrinación de Alpha, considerada un clásico en el género de viajes en la Nueva Granada, fruto de las expediciones de Ancízar como secretario de la Comisión Corográfica. En 1849 la imprenta de El Neogranadino publicó también el Teatro Social del siglo XIX, del español Modesto Lafuente (Fray Gerundio). También se encuentran muestras de costumbrismo en La Siesta, editada por Rafael Pombo y José María Vergara en 1852, en El Album (1856-1859) de José Joaquín Borda y en la Biblioteca de Señoritas (1858-1859), de Rafael Eliseo Santander y Felipe Pérez ${ }^{52}$.

\footnotetext{
${ }^{50}$ Henríquez Ureña, Las corrientes literarias.

${ }^{51}$ Efraín Sánchez, "Ramón Torres Méndez y la pintura de tipos y costumbres", Boletín Cultural y Bibliográfico, no. 28 (1991).

52 José Olinto Rueda, “Prólogo”, en Manuel Pombo. De Medellín a Bogotá (Bogotá: Banco de la República, 1992).
} 
La literatura costumbrista era por definición sumamente variada y en la época se escribían también los cuadros de la naturaleza, que se consideraban una vertiente del género, en los que se describían y alababan paisajes impresionantes, donde sobresalía lo descomunal, pero donde también se expresaba una visión centralista: el salto del Tequendama, en las afueras de Bogotá, era la maravilla de la naturaleza granadina, que rivalizaba con el Niágara.

Por lo general, cuando se presentaron obras originales, estas tomaban como marco geográfico las fronteras de colonización en las tierras bajas, llamadas la tierra caliente o las mismas costumbres de la ciudad. También se encuentran relatos sobre la ruta entre Bogotá y otras ciudades, Tunja, Medellín o Popayán. La ausencia del Caribe es otra vez notoria, para no hablar de la práctica inexistencia de regiones todavía limítrofes en el imaginario nacional, como el Pacífico, la Amazonía o los Llanos Orientales. Las descripciones estaban casi siempre restringidas al interior del país. Cuando no se trataba de ciudades, que por lo general tenían quienes las elogiaran y las describieran en sus particularidades, la regla era no dar nombres. El pueblo de E... de la tierra caliente o la parroquia X de la sabana de Bogotá eran modelos que pretendían representar los pueblos de toda la Nueva Granada, en los que se daba una idea general de los tipos y de las costumbres populares y de la configuración social y "moral" del pueblo, o en los que se daba cuenta de los vicios del sistema político y su funcionamiento en la práctica. Esto hace posible dividir los cuadros de costumbres en dos vertientes, una crítica, que se asemeja a una literatura de tesis, y otra puramente descriptiva. En el costumbrismo, en fin, confluyó el esfuerzo por construir una imagen del pueblo portador de la soberanía nacional, con la crítica de las costumbres populares y de la "moral pública".

Ahora bien, es importante anotar que no se llegó a una descripción rigurosa y homogénea de todos los componentes de la nación. Por ejemplo, mientras que el tipo indígena y el negro aparecen sólo marginalmente, el tipo del "calentano", el colono mestizo de las tierras bajas fue descrito con mayor frecuencia. De este, el tipo nacional por excelencia, objeto de frecuentes críticas, en donde se hallaba integrada la nación en sus componentes negro, blanco e indígena, los escritores solían resaltar su trato franco pero falto de buenas maneras, la simplicidad de sus costumbres y de su vestido, su alegría "natural" y su jovialidad. La oposición del bogotano, como un resultado de la civilización, además de todo expuesto a las modas extranjeras y al afrancesamiento era cosa corriente.

Pero las visiones del pueblo varían y esta visión romántica aparece moderada por las voces, a veces en extremo severas, que exigían un control al exceso de libertades públicas que permitía el ascenso de una temida barbarie. Un ejemplo de ello se encuentra en el número especial del 25 de junio que le consagró el Mosaico en su primer año a la fiesta popular del San Juan. Allí se encuentra lado a lado una poesía de Vergara y un cuadro de costumbres de José David Guarín, celebrando la fiesta, y un artículo criticándola, escrito por José Caicedo Rojas (firmado con su seudónimo "Celta"). 
Guarín, que se caracterizó por poseer una pluma burlesca, presentó un cuadro pintoresco titulado "Un día de San Juan en tierra caliente", en donde dejaba constancia de una visión condescendiente de las fiestas y sobre todo la visión romántica de la vida en comunidad campesina. Su escrito por cierto, tenía una virtud no tan corriente para los costumbristas, que como lo veremos más adelante no se fatigaron demasiado a la hora de buscar temas lejos de las ciudades. El suyo, por el contrario, era un cuadro sacado de una observación directa, hecha en un poblado en realidad no muy alejado de la tierra fría. Por eso, argüía el autor, la experiencia, la observación directa, había moderado la inclinación natural a juzgar "con el orgullo del recién llegado" una fiesta que por todo el pueblo era vista de manera más bien simpática y que, bien vista, revelaba virtudes integradoras y democráticas. Ella era una ocasión para que todo el mundo, propietarios y arrendatarios, blancos y mestizos, se encuentren como iguales. Así, a partir de una experiencia en la vida rural, el escritor se podía permitir una autocrítica que debía ser de buen recibo para quienes aspiraban a construir una literatura nacional:

Yo no sabía nada de eso [respecto a las fiestas], porque era la primera vez que salía de mi casa y allá no había leído sino novelas y periódicos y estos raras veces dicen algo de nuestras costumbres, y si a veces los literatos hacen alguna cosita, buscan asuntos en otras partes: todo a la europea ${ }^{53}$.

Por lo demás, es difícil pensar que su excursión al mundo rural le hubiera producido más que una vaga nostalgia romántica a Guarín, quien comparaba la felicidad de las ciudades a la dicha sencilla de los modestos campesinos ${ }^{54}$. El elogio de las cosas hermosas que podían disfrutarse y que debían ser rescatadas no le podía hacer olvidar la orientación última de la sociedad, así fuera para recordar en tono irónico la inevitabilidad de una regeneración a la europea sobre la base de unos peregrinos logros locales:

Siglos vendrán en que nuestra sociedad se haya regenerado al influjo de la civilización y en que nuestras costumbres sean enteramente francesas y el bambuco será repetido como un recuerdo siempre agradable: la marsellesa y el bambuco no morirán 55 .

En el mismo número en el que se consagra de esta manera la fiesta del San Juan, aparece el artículo de Caicedo, quien opinaba sobre la necesidad de crear controles a la fiesta. En

\footnotetext{
${ }^{53}$ El Mosaico, no. 26 (25/06/1859).

${ }^{54}$ Estas son sus palabras: "Yo no sé si en los grandes salones y en medio de las riquezas haya un instante siquiera que semeje la felicidad y la inocente sencillez que se goza en escenas de esta naturaleza. Allí, en medio de la naturaleza hay encantos que no han saboreado nunca los de las grandes ciudades y los ricos salones donde impera una tirante cortesía llevada hasta el extremo". Ibídem.

Este es un tema recurrente en los escritos de Guarín. En otro artículo aparecido en El Mosaico, titulado "La camisa calentana”, dedicado a encomiar a las mujeres de las tierras bajas, (cosa que hará magistralmente Eugenio Díaz en su Manuela quien hizo de la "mujer del pueblo" un símbolo nacional) éste escribe: "Y que parecerá un baile donde reina la franqueza [...] donde hay bocas frescas sin desdén, ojos quemadores sin altivez; fuego y dulzura, amabilidad y recato, sencillez y elegancia?". El Mosaico, no. 34 (20/08/1859).

${ }^{55}$ El Mosaico, no. $26(25 / 06 / 1859)$.
} 
particular, escribía contra la práctica ritual aceptada por la costumbre de decapitar un gallo, en la que encontraba una muestra de salvajismo y de corrupción moral del pueblo ${ }^{56}$. Su estilo, de hecho, en lo que tenía de desprecio hacia el populacho, llegó a caracterizar otras plumas que tendieron a ver en expresiones populares menos estruendosas, síntomas de una irremediable degeneración de las costumbres ${ }^{57}$.

Pese a todo, estas excursiones hacia el mundo rural, que ya se extendían hasta la periferia de Bogotá, no es la norma en los relatos de costumbres que se publicaron en El Mosaico, que con tanta mayor frecuencia fustigaron la pérdida de las tradiciones ancestrales, de los usos y costumbres y las irrupción de las modas europeas en la ciudad, en particular de Bogotá.

En este terreno, se dieron muestras de una verdadera voluntad de restituir costumbres entradas en desuso o que por típicas venían perdiendo estatus frente a otras que demostraban un mayor cosmopolitismo. Es el caso por ejemplo, de los cuadros dedicados a los aguinaldos, las cabañuelas, o a la penitencia ${ }^{58}$. De hecho en sintonía con la queja citada de Guarín, los tipos más presentes correspondían a la vida en la ciudad ${ }^{59}$. La cuestión de la identidad de la clase alta era por supuesto un tema de permanente actualidad, en el que fueron también convergentes las quejas contra el afrancesamiento y la defensa de una edad dorada del buen gusto: la de la generación revolucionaria, de los padres de la patria.

En este sentido se escribieron varios artículos contra el lujo, encarnado en la moda de la crinolina, que suscitaba un debate en las páginas sociales y que fue además satirizada en varios poemas y artículos de costumbres. Esta polémica, que no constituía una crítica contra el libre cambio -lo que se llegó a proponer fue una crítica contra la riqueza fácil de los comerciantes y contra el gasto excesivo en objetos de lujo- sino más bien contra la moda en sí y contra los nuevos valores que representaba, no sólo era una reacción de la cultura heredada de los antepasados contra el afrancesamiento servil, sino que en ella se mezclaban elementos de contradicción por el cambio social. Así por ejemplo, en el artículo "Antes y ahora" dedicado a las "lectorcitas del Mosaico" firmado por "un colombiano",60 , no sólo se criticaba el uso de la crinolina, sino que además se recriminaba la degeneración del gusto de las jovencitas, con respecto a los tiempos de la Gran Colombia y la intromisión de costumbres extranjeras, como la de tomar el té en lugar del chocolate.

\footnotetext{
${ }^{56}$ Sus palabras se caracterizan por un tono severo: "yo no siento que descabecen los gallos esos grupos ebrios e insanos de muchachos y gentes brutales", ese "populacho enfurecido", decía, al tiempo en que convenía irónicamente que el gallo, símbolo de la Francia de Napoleón III, bien merecía ese castigo de parte de un pueblo que se decía "liberal y republicano". Y terminaba anotando que lo que le preocupaba era que se llevara a los niños a presenciar un espectáculo que "los habitúa a la crueldad, a la insensibilidad, a cuanto puede pervertir el corazón y excitar las pasiones". "El san Juan", Ibídem.

${ }^{57}$ Es el caso de un cuadro de costumbres de José Caicedo y Rojas sobre el tiple, en donde el autor dice que este instrumento no es más que una degeneración de la noble guitarra española.

58 "Pagar penitencia": así se decía cuando alguien iba a una casa a hacer visita "casualmente" a la hora de comer.

59 Entre tanto, varios autores no ocultaban cierta perplejidad por el interés de algunos extranjeros hacia las costumbres de la gente del campo.

${ }^{60}$ Entonces, cuando Colombia se llamaba Confederación Granadina, ser colombiano significaba haber nacido en el breve período de existencia de la Gran Colombia.
} 
Vosotras, siguiendo la corriente y el impulso de la moda, habéis querido sustituir el excelente, el sabroso, el nunca bien, como se debe, alabado chocolate, por una decocción que aquí se llama té, y que en realidad no se sabe lo que es [...] ¿En donde tenéis, bellas lectoras, el gusto y aun el buen sentido para proscribir una costumbre nacional, que hoy es bien recibida y aceptada en las mejores sociedades del viejo mundo? ${ }^{61}$

Pero también esa exaltación y al mismo tiempo consagración de las costumbres nacionales se acompañaba de una condena contra los bailes, que según el autor anónimo, más parecían orgías permitidas por los padres, "que aplicando el sistema de Bentham a las polkas y schotises de sus hijas, hallan en ellas mayor suma de placeres que de penas" ${ }^{\text {"62 }}$. Moralismo y nacionalismo parecen dos cosas que van bien de la mano en esta época. Y esto no constituye una apreciación tan ligera como lo puede parecer. La sensación de una discontinuidad en las costumbres "nacionales" está muy presente en los cuadros de costumbres relacionados con la vida urbana, en los que se advierte la añoranza de los tiempos de Santafé, que se vuelven en cierta medida portadores de una cultura legítima y auténtica. Aunque por la misma vía se operaba una especie de reacción contra el modo de vida burgués, y se recordaba la pérdida de los criterios de distinción asociados al modo de vida nobiliario: los títulos y los apellidos. Es el caso por ejemplo del breve cuadro de costumbres "Los dos gatos", de Juan Francisco Ortíz, en donde el autor defiende el pudor y castidad de la mujer. En el inicio del cuadro, donde se habla de la índole de sus personajes, el autor constata los bruscos cambios en los valores de la sociedad:

En una casa de huéspedes de esta ciudad viven dos señoritas, de dieciocho años de edad; y al decir señoritas no quise afirmar que son de sangre azul, ni que están emparentadas con las familias principales que en otro tiempo tenían títulos de Castilla. El día de hoy una muchacha es canalla y vulgo, por más linda que sea, si no calza botines y no gasta crinolina; pero en compensación cualquier moza que se pone saya de seda y mantilla de punto pasa por señorita, aunque en presencia de la filosofía y del sentido común, se quede siendo lo que es: una joven, una moza, una muchacha ${ }^{63}$.

En este sentido, las comparaciones entre "antes y ahora" fueron reiteradas, arrojando casi siempre un valor positivo el "antes", sobre todo en cuanto concierne las prácticas de la elite, que debía ser conservadora para preservar su carácter. Sin embargo muchas veces se reflejaban paralelamente verdaderos cuestionamientos de los valores asociados a la modernidad que repuntaban en el alma de las gentes; ya por ejemplo, se decía, nadie prestaba dinero, todo era interés, usura, no existía una verdadera fraternidad, en lo que se describió como una irrupción

\footnotetext{
${ }^{61}$ El Mosaico, no. 14 (26/03/1859). Debe ser en esta década de 1860 en que el chocolate se vuelve la bebida tradicional en Bogotá. Una crítica semejante se encuentra en "Las tres tazas": José María Vergara, Las tres tazas (Bogotá: Minerva, 1933).

${ }^{62}$ El Mosaico, no. $14(26 / 03 / 1859)$.

${ }^{63}$ El Mosaico, no. $42(26 / 10 / 1860)$.
} 
del "yanquismo", considerado desde entonces como un modelo de vida contrario al genio nacional ${ }^{64}$.

En fin, las elites se van dibujando un carácter propio, que ya no sólo gira en torno al republicanismo, sino que invoca unas maneras y reivindica unos usos ancestrales que la identifican en relación con lo extranjero. Socialmente se reconocen las formas propias, lo que no es poca cosa, y ya se empieza a hablar de tipos específicos del mundo social, como el ser anfibio de los hijos naturales tan comunes en la sociedad colombiana, a mitad de camino siempre entre las altas esferas y el pueblo raso, sin pertenecer definitivamente a ninguna de las dos.

En el último aparte, que sigue a continuación, veremos un intento original del director de $E l$ Mosaico por explicar la identidad de la nación entera, donde se ve cotejado ese imaginario de unidad, homogeneidad e indivisibilidad de la nación europea (que es una aspiración) con la realidad de una Colombia federada y mestiza.

\section{La nación según Vergara: una raza cósmica avant la lettre}

En el último capítulo de su Historia de la literatura en Nueva Granada $(1867)^{65}$, José María Vergara, tratando el problema de la poesía popular colombiana, ofrece un discurso original sobre la nación colombiana en la época del federalismo. Aunque el capítulo a que hacemos referencia ha sido objeto de otras lecturas ${ }^{66}$, acá sostenemos que en él se trasluce la aspiración al mestizaje, como única forma de aniquilamiento de la diferencia que impedía a ojos de Vergara, que la nación correspondiera a una unidad cultural y racial y en últimas, que fuera una nación popular. El proceso de mestizaje, por ser de largo plazo justamente, sería un proceso no violento, y más que eso, sería aleatorio, ya que respetaría los ritmos de la "regeneración"

64 Los Editores, "Fraternidad de la época (correspondencia contemporánea auténtica)”, El Mosaico, no. 14 (26/03/1859). Después de mostrar una correspondencia "auténtica" en la que uno de los corresponsales se niega a prestar dinero, escriben los editores: "Damos lugar a la correspondencia que precede no porque estemos de acuerdo con las ideas que envuelven las cartas de Y. Z. contra cierta clase de la sociedad [contra los ricos], sino porque ella tiende a marcar una era muy notable en Bogotá; la era de la metalización y del egoísmo: la era del yanquismo". La crítica al "yanquismo", opuesta al espiritualismo de América del sur se va haciendo corriente en esta década; para llegar a su expresión más acabada en el poema de José María Torres Caicedo "América Latina" (1864) que consagra el nombre del subcontinente. Vicente Romero, "Du nominal «Latin» pour l'autre Amérique. Notes sur la naissance et le sens du nom «Amérique Latine» autour des années 1850". Histoire et Sociétés de l'Amérique Latine, no. 7 (1998): 57-86.

Sobre la crítica de los Estados Unidos se encuentra además en El Mosaico una novela del español Antonio de Trueba titulada "Desde la patria al cielo", en donde se narran los viajes por América de un joven español, quien llega a una América católica que lo consuela con su espiritualidad tras su paso por los Estados Unidos, país de materialistas.

${ }^{65}$ El libro fue terminado en 1861, pero sólo fue publicado en 1867. Quizás este último capítulo no fue escrito sino para el momento de la edición del libro.

${ }^{66}$ Olga Restrepo, "En busca del orden: ciencia y poder en Colombia", Asclepio. Revista de Historia de la medicina y de la ciencia, vol 50, no.-2 (1998): 33-75. Restrepo pone el acento en los aspectos que indican propósitos racistas y excluyentes. 
genética de la nación. En este proceso, además ni la educación, ni la Iglesia o el Estado, cumplen ningún papel. Antes, sin embargo, cabe anotar algunas precisiones sobre la obra.

El plan general del libro era deliberadamente limitado. Este se centraba en unos objetivos bien precisos. Por una parte, estaba la idea de contestar la tesis "sentada por los políticos", "según la cual antes de 1810 no había existido en la Nueva Granada un movimiento intelectual digno de memoria". En ese sentido, la obra recogía, siguiendo un orden cronológico, todas las referencias que venían a evidenciar lo contrario, y para ello el autor no vacilaba en incluir referencias dudosas o supuestas, que vinieran a aumentar el caudal de los trabajos, especialmente poéticos, escritos en castellano por colombianos. Para ello en últimas es que Vergara había consagrado tanto tiempo como bibliógrafo. Como lo decía en las conclusiones felicitándose, lo importante, que era "hacernos presentes en el mundo civilizado como un pueblo intelectual, no escaso de ingenio ni de inventiva", se había logrado. El trabajo cobijaba en realidad un interés histórico, objetivo, pero también otro afectivo y simbólico. Además, constituía una amarra estratégica con una cierta antigüedad española. Vindicando el tronco común, por la lengua, la elite cultural se hacía heredera legítima de un pasado antiguo, del mundo latino, y por esa vía de la civilización occidental, cuyos lazos actualizaba permanentemente en la literatura y a través de los viajes, para no hablar de las instituciones. Así, partiendo de los textos atribuidos al conquistador de la capital, Gonzalo Jiménez de Quesada, (heredero del siglo de oro) incluyendo obras que hasta ahora no han sido encontradas y de las cuales a veces sólo se tiene su título, la obra muestra una tradición literaria que se forma en paralelo a los desarrollos de la ya antigua tradición española, que constituye el fondo común de una tradición literaria supranacional ${ }^{67}$. Esa ramificación, a juicio de Vergara, nunca habría logrado sus más grandes fracasos que cuando trataba de declararse independiente de su verdadera tradición española. Sobre todo si al rechazar a España se acercaba peligrosamente (por las veleidades cosmopolitas de los liberales) a un gran enemigo de siempre cediendo a la seducción de la literatura francesa, un modelo falso que llevaba a la negación de la identidad nacional.

Por otra parte, se trataba en un contexto particularmente complicado, de hacer una vindicación de la Iglesia. La Historia de Vergara en efecto no se limitaba a demostrar documentalmente el error de quienes acusaban de ignorancia y oscurantismo a las instituciones coloniales, sino que pretendía de paso comprobar que era justamente a la Iglesia a la que se le debían los mayores esfuerzos y méritos en el cultivo de las letras y en la obra de la civilización. Fechada el 20 de julio, en la Introducción del libro se lee: "Quise escribir solamente una historia literaria [...] Mas, ya que lo que buscaba, las letras, lo encontré siempre en el seno de la Iglesia misma, no tenía para que negar que me es muy grato reunir las glorias de la Iglesia a las de la patria"68.

En fin, regresando al último capítulo, que es al que hemos hecho referencia más arriba, Vergara trataba allí un tema enorme, al que no le dedicaba más que unas pocas páginas. Su problemática podría hasta cierto punto ser calificada de teórica, porque ciertamente permanece en el campo

\footnotetext{
${ }^{67}$ No debe extrañar esto en Vergara, quien fue el encargado de diligenciar en Madrid en 1871 la creación del estatuto de academias americanas correspondientes de la Real Academia Española.

${ }^{68}$ Vergara y Vergara, Historia, 24.
} 
de lo hipotético. La pregunta por la existencia o no de una "poesía popular", lo llevaba a plantearse a su vez otra sobre la existencia, y entonces sobre la naturaleza, del pueblo colombiano, teniendo en mente una idea más o menos precisa de lo que debería ser un pueblo al que se le pudiera calificar de "nacional": un pueblo con una misma lengua y origen, con unas mismas tradiciones así como con una homogeneidad racial, cultural e histórica. Ahora bien, en Colombia era forzado comprobar que una nación así definida no cumplía sino con el requisito de la lengua:

[En el siglo XVIII] hablaba ya todo el pueblo el lenguaje conquistador; pero ese pueblo estaba compuesto de grupos heterogéneos amoldados en uno por la fuerza y no por la similitud de orígenes y tradiciones ${ }^{69}$.

Pero esta circunstancia especial, esta heterogeneidad, que definía como rasgo general a la nación, hacía al mismo tiempo imposible precisar sus atributos. Sólo el proceso de mestizaje, que implicaba la aculturación y el sincretismo, podría contribuir a dar una fisionomía tipo a los colombianos. Era de esperarse que este panorama de heterogeneidad tuviera como conclusión la unidad; una unidad racial e histórica que permitiera construir una memoria colectiva y unas tradiciones verdaderamente populares.

No teniendo ese pueblo heterogéneo una historia anterior, propia del país donde se reunió, no podía hacerse popular la poesía. Se necesitaban muchas generaciones para que el negro olvidara su patria, y amara ésta; el indio se acostumbrara a mirarse como paisano del blanco y del negro; y el blanco olvidara totalmente su patria española y tuviera recuerdos de antepasados americanos. Cuando ya por ministerio del tiempo se unificaron los recuerdos y hubo patria común, quedó en pie otro inconveniente, el de la antipatía de las razas. Para que acabe de desaparecer este obstáculo, y las tres razas, absorbiéndose y tomándose cualidades, formen una sola y reúnan por fin en un solo pasado sus recuerdos, es menester que pase otro gran periodo de tiempo. Algo de esto se consiguió con la guerra de independencia, que dio recuerdos de desgracias comunes y de glorias hermanas; pero ese algo no es gran cosa todavía ${ }^{70}$.

La misma idea de pueblo, caracterizado por la unidad de lengua, cultura, tradición y raza, determina la aspiración de ver en el futuro lejano aparecer un "gran pueblo colombiano", donde las tres razas se encontrarían fundidas e una única comunidad "singular", con recuerdos unificados y tradiciones comunes ${ }^{71}$.

\footnotetext{
${ }^{69}$ Ibídem, 205.

${ }^{70}$ Ibídem, 206.

${ }^{71}$ En el ascenso de esa nación mestiza, si bien aún no se había llegado a cantar romances históricos (como el de Ossian), considerada la producción más elevada de la poesía popular, se disponía de una música popular, el bambuco, considerado "enteramente nacional", que sentían como suyo ricos y pobres (aunque en realidad se excluía al Caribe colombiano): "[El Bambuco] es de todas nuestras cosas lo único que encierra verdaderamente el alma y aire de la patria. El granadino que oiga hablar español en Esmirna o Jerusalén sentirá un vivo placer, pero se dirá ¿esa voz es
} 
Por otra parte, si algo podría destacarse en este ensayo de Vergara, es que para él, la relación del pueblo con su gobierno no constituye el factor decisivo de la nacionalidad. En contraste con la nación de ciudadanos que proclamaban los liberales, su ideal de nación es la comunidad vinculada por un sentimiento colectivo, que comparte un mismo pasado y unos mismos ancestros heroicos.

Para concluir, Vergara no omite un problema fundamental de ese devenir nación en la segunda mitad del siglo XIX: el federalismo. Según él, esta es una forma de gobierno adecuada a la realidad, a la divergencia de los pueblos (asimilados a regiones o Estados en este caso) ${ }^{72}$; pero igualmente, es una forma estacionaria que está lejos del ideal de homogeneidad que da cuerpo a las naciones y de la corriente de la historia. Visto desde esa perspectiva, el federalismo suponía una lógica de competencias regionales que sólo se resolvería con la hegemonía de una de las variantes:

Todos estos tipos de la república no han sido todavía fundidos en uno solo; y pasará un siglo o dos antes que suceda. ¿Ese día habrá un gran pueblo? Difícil es preverlo. Que dominen ciertos caracteres, y será una nación de tercer orden; que tomen la delantera otros, y será una gran nación.

Nuevamente, Vergara dejaba entrever que el proceso de consolidación de la nación sería lento y aleatorio. Dos siglos y medio, quizás tres era el plazo que daba para verla como una nación regenerada, madura en fin, con unas cualidades de raza definidas, para bien o para mal.

No obstante, lo que no observa Vergara es que ya para 1867 el proceso de reunificación de la nación se halla en marcha. La fragmentación del poder nacional se presentaba desde entonces como un escollo para las mismas elites liberales que, buscando abstraerse de "la tiranía" de Mosquera, habían acabado parcelando al Estado hasta el punto de reducir al mínimo su capacidad de influencia.

Poco después un "movimiento nacional", patriótico, identificado en buena medida con los círculos eruditos hispanófilos y católicos, impone un nuevo término al proceso de consolidación de la unidad nacional que, contrario a los ideales liberales, significaba mirar hacia el pasado. "Regeneración o muerte" pronunciará Nuñez; pero no a cualquier precio, dirá Caro, quien complementaba con la frase que dará contenido a esa época de la historia nacional: una nación, una religión, una lengua.

\footnotetext{
granadina, americana o española? Mas si oyese preludiar un bambuco, gritara, corriendo hacia el músico: ¡es mi patria; el que eso toca me conoce o yo lo conozco!”. Ibídem, 215.

${ }^{72}$ En esta parte, cuando Vergara hace referencia a los "pueblos que forman el conjunto de la que hoy es República de Colombia". se refiere a los diferentes Estados. Así continúa diciendo "La política la ha dividido en nueve Estados de apellido soberanos; y como es natural que la misma política sostenga por muchos años esta división, la adoptaremos para clasificar los caracteres". Ibídem.
} 
En el fondo sin embargo, la victoria de esta nación no fue como lo suponía o esperaba Vergara, el fruto de un lento proceso de asentamiento, sino el saldo de una victoria (y una derrota) política y militar.

\section{Conclusión}

Hemos visto como El Mosaico sirvió para la fabricación cultural de la nación colombiana en la segunda mitad del siglo XIX. También hemos mostrado cómo ella sirvió de centro de formación de las elites culturales colombianas.

La época de aparición de la revista, el contexto político especial de esos años de conciliación bipartidista, explica varias cosas sobre la publicación. A mediados del siglo XIX, se puede identificar por primera vez en Colombia una elite nacional preocupada fuertemente por los temas de la literatura y la cultura. Modelada por los acontecimientos recientes, especialmente por la dictadura de Melo y el ascenso del radicalismo con sus influencias socialistas, se observa una disposición de las capas más encumbradas, con valores muchas veces tradicionalistas, por crear un frente común contra los planteamientos modernos de la igualdad y la mercantilización de los espíritus. Que El Mosaico no fuera una lectura popular puede además explicarse hasta cierto punto por las consecuencias que en un momento dado pudieron sacar las elites sobre los efectos de la popularización de la prensa y de las asociaciones políticas, sobre sus usos demagógicos y politiqueros. A esto se puede achacar el elitismo de la revista y también puesto que las mismas circunstancias mostraban la necesidad y la oportunidad de estrechar lazos por fuera de la política entre las diferentes elites regionales, con base en unas comunes competencias culturales.

Pero en últimas, ¿qué puede decirse sobre la imagen de nación que trataba de proyectarse en la revista? Es difícil decir que la imagen que la acompaña es la de una Colombia rural. Es más, como lo deja ver Vergara, se entendía que ese país rural apenas estaba formándose. El pueblo era visto en transformación permanente, en un proceso de asimilación y mestizaje y no podía aparecer como el depositario de un legado ancestral transmitido de generación en generación. Algo del fundamento de la nacionalidad se buscaba desde entonces en las culturas indígenas, pero el indigenismo por muchos motivos no tuvo la misma amplitud que en México, por ejemplo.

Más bien, lo que la revista refleja es el afán de consolidar la imagen tanto hacia adentro como hacia fuera de un país urbano y culto, donde la civilización latina había echado raíces y prosperaba formando una tradición propia. El Mosaico, en efecto, sería uno de los vectores del mito de la Atenas suramericana. 
Anexo 1

Suscriptores de El Mosaico en 1860 en Bogotá

\begin{tabular}{|c|c|c|}
\hline Adolfo Adams & Francisco Bayón & Lino de Pombo \\
\hline Alejandro Caicedo & Francisco de P. Restrepo & Lorenzo María Lleras \\
\hline Alejandro McDowal & Francisco E. Ruiz & Lucio Pinzón \\
\hline Alejandro Osorio & Francisco Ospina & Macías Emilio Escovar \\
\hline Andrés Santamaría & Fructuoso Castillo & Manuel Manrique \\
\hline Angel Cuervo & Gaspar Díaz & Manuel María Madiedo \\
\hline Angel María Galán & Gavino Liévano & Manuel Umaña \\
\hline Antonio Acero & George Jonnes, excmo. Sr. & Marco de Urbina \\
\hline Antonio B. Pineda & Gregorio de J. Fonseca & Mariano Calvo \\
\hline Antonio Gardeazábal & Gregorio Obregón & Mariano Ospina \\
\hline Antonio R. de Narváez & Gutiérrez Lee, excmo. Sr. & Medardo Rivas \\
\hline Antonio Rei & Hermógenes Saravia & Miguel Gutiérrez \\
\hline Antonio Vargas Reyes & Ignacio Gutiérrez & Miguel Vargas \\
\hline Antonio Vargas Vega & Ignacio Ortega & N. Lindig \\
\hline Bartolomé Calvo & Ignacio Ortiz & Narciso González \\
\hline Benigno Barreto & Ignacio Ospina & Nazario Lorenzana \\
\hline Bernardo Espinosa & J. Francisco Samudio & Néstor Escovar \\
\hline Bernardo Herrera & J. María Gutiérrez Restrepo & Nicolás Pereira Gamba \\
\hline Bonifacio Uricoechea & Jerónimo Martínez & Pastor Ospina \\
\hline Bruno Pulecio & Gervasio Saunier & Pedro Fernández Madrid \\
\hline Buenaventura Seoane & Jesús María Gutiérrez & Pedro Rojas \\
\hline Carlos Martin & José Belver & Rafael de Porras \\
\hline Carlos Schloss & José Feliz Merizalde & Rafael Escallón \\
\hline Clemencia Caicedo & José María Junguito & Rafael Samper \\
\hline Cornelio Borda & José María Plata & Ramón Argáez \\
\hline Daniel Ayala & José María Portocarrero & Ramón Guerra Azuola \\
\hline Daniel Granados & José María Quijano Otero & Ricardo Santamaría \\
\hline Domingo Azuola & José María Rubio Frade & Ricardo Silva \\
\hline Emeterio Heredia & José María Saravia Ferro & Sabas Uricoechea \\
\hline Emigdio Briceño & José María Tejada García & Santiago Bourdon \\
\hline Enrique Umaña & José María Zarate Ramírez & Teodoro Valenzuela \\
\hline Enriqueta Montoya & José Segundo Peña & Teófilo del Río \\
\hline Eusebio Bernal & Juan Antonio Marroquín & Timoteo Maldonado \\
\hline Eustacio Latorre & Juan de Dios Muñoz & Tomas Cuenca \\
\hline Evaristo Escovar & Juan de Dios Riomalo & Venancio Manrique \\
\hline Felipe Roa & Juan N. Mora Jiménez & Venancio Restrepo \\
\hline Feliz Saiz & Juan Ujueta & Vicente Lombana \\
\hline Fidelia Rodríguez & Julián Pardo & Wenceslao Uribe Angel \\
\hline Francisco Angarita & Lino Amado Castro & Zoilo Silvestre \\
\hline
\end{tabular}


Anexo 2

Colaboradores de El Mosaico años 1859, 1860 y 1865

\begin{tabular}{|c|c|c|}
\hline Adolfo Sicard y Pérez & Hermógenes Saravia & Manuel M. Párraga \\
\hline Adriano Páez & J. Cornelio Borda & Manuel María Madiedo \\
\hline Agripina Ancízar de Samper & J. M. Arrubla Q. & Marceliano Vélez Barreneche \\
\hline Andrés María Marroquín & J. M. Villergas & María del Pilar Sinués de Marco \\
\hline Angel María Galán & Jenaro Santiago Tanco & María Gregoria Logan \\
\hline Antonio B. Pineda & Jesús T. Tejada & Mariano G. Manrique \\
\hline Aurelio Sicard & Joaquín Pablo Posada & Mariano Rementería \\
\hline Belisario Peña & Jorge Isaacs & Miguel Antonio Caro \\
\hline Benjamin Pereira Gamba & José Benito Gaitán & Miguel Tobar Serrate \\
\hline Bernardino Torres Torrente & José Caicedo Rojas & Pedro Alcántara Herrera \\
\hline Carlos T. Irwin & José David Guarín & Prospero Pereira Gamba \\
\hline Coronel Tello & José Joaquín Borda & Prudencio Rei \\
\hline Custodio Ripio & José Joaquín Ortíz & R. García V. \\
\hline D. Díaz Granados & José Manuel Lleras & R. M. Gaitán \\
\hline Daniel A. Cardona & José Manuel Marroquín & Rafael Eliseo Santander \\
\hline Darío Valencia & José María Alemán & Rafael Pombo \\
\hline Domingo Martínez & José María Pinzón Rico & Rafael Romero Bermúdez \\
\hline E. Florentino Sanz & José María Quijano Otero & Rafael Vergara y Vergara \\
\hline E. P. de Escrich & José María Samper & Ramón Jiménez de León \\
\hline Enrique Umaña Ricaurte & José María Vergara y Vergara & Ricardo Carrasquilla Ortega \\
\hline Ernesto M. Sicard & José Mariano Melendro & Ricardo Silva \\
\hline Eugenio Díaz & Josefa Massanes & Romualdo Cuervo \\
\hline Eugenio Orjuela & Juan Clímaco Arbeláez & Ruperto S. Gómez \\
\hline Eusebio Blasco & Juan Francisco Ortíz & Silveria Espinosa Pendón \\
\hline Ezequiel Uricoechea & Leopoldo Borda & Simón B. O’Leary \\
\hline Felipe Pérez & Lorenzo María Lleras & Soledad Acosta de Samper \\
\hline Félix Saiz & Lucio Pinzón & T. M. Muñoz \\
\hline Francisco Bayón & Luis Rodríguez Velasco & Venancio Ortíz \\
\hline Gabriel Sandino & Manuel Ancízar & Vicente Holguín \\
\hline García Gutiérrez & Manuel B. Castillo & Wenceslao Montenegro \\
\hline Gregorio Gutiérrez González & Manuel D. Carvajal & \\
\hline Guillermo Matta & Manuel de Palacio & \\
\hline
\end{tabular}




\section{Bibliografía}

\section{Fuentes primarias}

Anuario de la Academia Colombiana de la Lengua. 1874-1910. Tomo 1. Reimpresión con Adiciones. Bogotá: Imprenta Nacional, 1935.

Acosta, Joaquín. Historia del descubrimiento y colonización del Nuevo Reino de Granada. Bogotá: Biblioteca Nacional, 1942.

Caro, Miguel Antonio. Obras completas de don Miguel Antonio Caro. Bogotá: Imprenta Nacional, 1923.

Escritos políticos, primera serie. Bogotá: Instituto Caro y Cuervo, 1990.

Cuervo, Ángel y Rufino José. Vida de Rufino Cuervo y noticias de su época. París: A. Roger y F. Chernoviz, 1892.

El Mosaico (años I, II y IV. Dic. 1858- dic. 1860 y ene 1865 -dic. 1865).

Martínez Silva, Carlos. "Bibliografía”. La Caridad, vol. 3, no. 33 (22/03/1867).

Tres colombianos: esbozo crítico-biográfico. [Bogotá? : s.n., 1895?].

Ortiz, Juan Francisco. Reminiscencias de D. Juan Francisco Ortíz (opúsculo autobiográfico 1808-1861) con prólogo de D. José Manuel Marroquín. Bogotá: Librería Americana, 1907.

Plaza, José Antonio de. Compendio de la historia de la Nueva Granada, desde antes de su descubrimiento hasta el 17 de noviembre de 1831, para el uso de los colegios y universidades de la República. Bogotá: Imprenta del Neogranadino, 1850.

Quijano Otero, José María. Compendio de historia patria. Bogotá: Imprenta de Medardo Rivas, 1874.

Romero, Mario Germán, ed. Epistolario de Ezequiel Uricoechea con Juan María Gutiérrez, varios colombianos y August Friedrerich Pott. Bogotá: Instituto Caro y Cuervo, 1998.

Vergara y Vergara, José María. Historia de la literatura en Nueva Granada. 2 tomos. Bogotá: Biblioteca Banco Popular, 1974.

\section{Fuentes secundarias}

Agulhon, Maurice. Le cercle dans la France bourgeoise 1810-1848. Etude d'une mutation de sociabilité. Paris: Armand Colin, 1977.

Anderson, Benedict. Comunidades imaginadas: Reflexiones sobre el origen y la difusión del nacionalismo. México: FCE, 1992.

Baggioni, Daniel. Langues et nations en Europe. París: Payot, 1997.

Besterman, Theodore. The Beginings of Systematic Bibliography. Oxford y Londres: Oxford University Press/ Humphrey Milford, 1935.

Bushnell, David. "The Developpment of the Press in Great Colombia". Hispanic American Historical Review, no. 30 (1950): 432-452. Colombia una nación a pesar de sí misma. Bogotá: Planeta, 1996. 
Cacua Prada, Antonio. Historia del periodismo colombiano. Bogotá: Fondo Rotatorio Policía Nacional, 1968.

Chartier, Roger. Culture écrite et société. L'ordre des livres (XVIe-XVIIIe siècle). París: Albin Michel, 1996.

Colmenares, Germán. "La Historia de la Revolución, por José Manuel Restrepo: una prisión historiográfica". En Germán Colmenares et al. La Independencia. Ensayos de historia social. Bogotá: Colcultura, 1986.

Partidos políticos y clases sociales. Bogotá: Universidad de los Andes, 1968.

Deas, Malcom. Del poder y la gramática y otros ensayos sobre historia, política y literatura colombianas. Bogotá: Tercer Mundo editores, 1993.

Demelas, Marie Danielle y Yves Saint Geours. Jérusalem et Babylon. Politique et religion en Amérique du sud. L'Equateur XVIIIe-XIXe siècles. París: Recherche sur les Civilisations, 1989.

Duarte, Jesús y María V. Rodríguez. "La sociedad Filarmónica y la cultura musical en Santafé a mediados del siglo XIX". Boletín Cultural y Bibliográfico, no. 21, vol. 28 (1991).

Garrido, Margarita. Reclamos y Representaciones. Variaciones sobre la política en el Nuevo Reino de Granada, 1770-1815. Bogotá: Banco de la República, 1993.

"La Política local en la Nueva Granada, 1750-1810". Anuario de Historia Social y de la Cultura, no. 15 (1987): 37-56

"Propuestas de identidad política para los colombianos en el primer siglo de la República”. En Javier Guerrero, comp. Memorias del IX Congreso de Historia. Iglesia, movimientos y partidos: Política y violencia en la historia de Colombia. Vol. 3. Tunja: Universidad Pedagógica y Tecnológica de Colombia, 1995.

Gellner, Ernest. Nations and Nationalism. Ithaca, New York: Cornell University Press, 1983.

Gerbi, Antonello. La disputa del Nuevo Mundo. México: Fondo de Cultura Económica, 1960.

Gómez Restrepo, Antonio. Historia de la literatura colombiana. Bogotá: Ministerio de Educación Nacional, 1945-46.

González, Fernán. "Ciudadanía e identidad nacional. Los desafíos de la globalización y diferenciación cultural al Estado Nación". Ponencia presentada en el XI Congreso Colombiano de Colombia, Bogotá, Agosto del 2000.

"Relaciones entre identidad nacional, bipartidismo e Iglesia católica, 1820-1886". En Para leer la política. Ensayos de historia política colombiana. Tomo 2. Bogotá: Cinep, 1997.

Gordillo Restrepo, Andrés. El corazón y la norma. Aproximaciones al canon conservador del siglo XIX. Bogotá: Alcaldía Mayor de Bogotá, 2000.

Guerra, François-Xavier. Modernidad e Independencia. Ensayos sobre las revoluciones hispánicas. Madrid: Editorial MAPFRE, 1992.

Henríquez Ureña, Pedro. Las corrientes literarias en la América hispánica. México: Fondo de Cultura económica, 1949.

Hobsbawm, Eric. Nations and Nationalism since 1780. Programm, Myth, Reality. Cambridge: Cambridge University Press, 1992.

Hobsbawm, Eric y Terence Ranger, ed. The invention of Tradition. Cambridge: Cambridge University Press, 1983. 
Jaramillo Uribe, Jaime. "Nación y región en los orígenes del Estado Nacional en Colombia. En Problemas de la formación del Estado". En Ensayos de historia social. Tomo 2. Bogotá: Tercer Mundo Editores; Ediciones Uniandes, 1989.

Kaplan, Marcos. Formación del Estado nacional en América Latina. Santiago de Chile: Universitaria, 1969.

König, Hans-Joachim. En el camino hacia la nación. Nacionalismo en el proceso de formación del Estado y de la nación de la Nueva Granada, 1750-1856. Bogotá: Banco de la República, 1994.

Liévano Reyes, Roberto. "El mosaico: tertulias literarias en Santafé y Bogotá". El Gráfico 38, no. $375(20 / 10 / 1917)$.

Lomné, Georges. "Del reino a la nación: la invención del territorio colombiano". Aleph, no. 112, (2000): 2-9.

Marienstras, E. Les mythes fondateurs de la nation américaine. París: Maspero, 1976. Nous le peuple. Les origines du nationalisme américain. París: Gallimard, 1988.

Martínez, Frédéric. El nacionalismo cosmopolita. La referencia europea en la construcción nacional en Colombia, 1845-1900. Bogotá: Banco de la República; Instituto Francés de Estudios Andinos, 2001.

Martínez Delgado, Luis y Sergio Elías Ortíz. El periodismo en la Nueva Granada. Bogotá: Editorial Kelly, 1960.

Melo, Jorge Orlando. "La literatura histórica en la República". En Manual de Literatura Colombiana. 2 vols. Bogotá: Procultura; Planeta 1988.

Múnera, Alfonso. El fracaso de la nación. Región, clase y raza en el Caribe colombiano (17171810). Bogotá: Banco de la República; El Ancora editores, 1998.

Obregón Torres, Diana. Sociedades científicas en Colombia. La invención de una tradición 1859-1936. Bogotá: Banco de la República, 1992.

Otero Muñoz, Gustavo. "La pasión bibliográfica de Vergara y Vergara". El Gráfico 21, no. $1021(1931)$.

Palacios, Marco, ed. La unidad nacional en América Latina: del nacionalismo a la nacionalidad. México: El Colegio de México, 1983.

Palacios, Marco. "La fragmentación regional de las clases dominantes en Colombia. Una perspectiva histórica". En Estado y clases sociales en Colombia. Bogotá: Procultura, 1986.

Peñaloza, Juan José. “El centenario de Vergara y Vergara”. El Gráfico 21, no. 1020 (1931).

Restrepo Forero, Olga. La Comisión Corográfica, avatares en la configuración del saber. Bogotá: Universidad Nacional, monografías sociológicas, 1988.

"En busca del orden: ciencia y poder en Colombia". Asclepio. Revista de Historia de la medicina y de la ciencia 50, no. 2 (1998): 33-75.

Romero, Vicente. "Du nominal «Latin» pour l'autre Amérique. Notes sur la naissance et le sens du nom «Amérique Latine» autour des années 1850". Histoire et Sociétés de l'Amérique Latine, no. 7 (1998): 57-86.

Rueda, José Olinto. "Prólogo". En Manuel Pombo. De Medellín a Bogotá. Bogotá: Banco de la República, 1992. 
Sánchez, Efraín. "Ramón Torres Méndez y la pintura de tipos y costumbres". Boletín Cultural y Bibliográfico, no. 28 (1991).

Segura, Marta. Itinerario del Museo Nacional de Colombia. 1823-1994. Bogotá: Instituto Colombiano de Cultura; Museo Nacional de Colombia, 1995.

Silva Olarte, Renán José. Prensa y revolución a finales del siglo XVIII: contribución a un análisis de la formación de la ideología de independencia nacional. Bogotá: Banco de la República, 1988.

Silva Olarte, Renán José. La reforma de estudios en el Nuevo Reino de Granada 1767-1790. Bogotá: Universidad Pedagógica Nacional, 1981.

Tirado Mejía, Alvaro. "Colombia: siglo y medio de bipartidismo". En Jorge Orlando Melo, coord. Colombia Hoy. Bogotá: Presidencia de la República, 1996.

Thiesse, Anne Marie. La création des identités nationales. Europe XVIIIe-XXe siècle. París: Seuil, 1999.

Uribe Vargas, Daniel. Las Constituciones de Colombia. 2 vols. Madrid: Cultura Hispánica, 1977.

Urrutia, Miguel y Mario Arrubla. Compendio de estadísticas históricas de Colombia. Bogotá: Universidad Nacional de Colombia, 1970.

Vial Correa, Gonzalo. "La formación de las nacionalidades hispanoamericanas como causa de la independencia". Boletín de la Academia Chilena de Historia 33. No. 75 (1966): 110144.

Williams, Raymond. Novela y poder en Colombia. 1844-1987. Bogotá: Tercer Mundo editores, 1991.

Wilson, Jorge. "José María Vergara y Vergara”. Revista Gris 2, no. 10 (1894).

Fecha de recepción del artículo: 9 de junio de 2003

Fecha de aceptación: 22 de agosto 2003 